\title{
'To trust or not to trust': The impact of social media influencers on the reputation of corporate brands in crisis
}

\begin{abstract}
Corporates often partner with social media influencers to bolster brand image after crises. Although existing evidence suggests that influencers have a largely positive effect on brands, yet there is paucity of research on the role of influencers in corporate crisis communications. Across two studies, we examine the impact of influencers on consumers' perception of corporate brand in crisis. Drawing on persuasion knowledge theory, we identify pitfalls associated with influencers, such as inferences of manipulative intent, which negatively affect perceived trustworthiness and corporate reputation. The downside of engaging influencers in crisis communications can, however, be offset by influencer and the brand communicating values-driven motives of their partnership. Our findings imply that corporate brands should respond to crises through a bolstering strategy that promotes existing corporate goodwill, without influencer's involvement. When leveraging on influencers' support, however, brands should endeavor to inoculate manipulative inferences by communicating the values-driven motives behind the brand-influencer partnership.
\end{abstract}

Keywords: Corporate reputation; Corporate brand crisis; Influencer marketing; Persuasion knowledge; Crisis communications; Experiment 


\section{'To trust or not to trust': The impact of social media influencers on the reputation of corporate brands in crisis}

\section{Introduction}

The popularity of social media has prompted corporate brands to employ online personalities, who endorse the brand and influence followers' perceptions with their communications (WARC, 2019). These personalities, also known as social media influencers (hereafter SMIs), have amplified the popularity of influencer marketing globally (e.g., Lee \& Watkins, 2016; Schomer, 2019. Reports indicate that over two thirds of multinational brands around the world plan to increase expenditure on influencer marketing within the next few years (World Federation of Advertisers, 2018), with global spending in the area expected to reach $\$ 15$ billion by 2022 (Schomer, 2019). Popular SMIs include Zoella - beauty influencer (11 million YouTube subscribers), PewDiePie - gaming influencer (103 million YouTube subscribers), and Rosanna Pansino - food influencer (4.6 million Instagram followers). With such extensive followings, SMIs enable corporates to widen brand reach in an increasingly cluttered social media environment (Djafarova \& Rushworth, 2017). Brands enter into a partnership with SMIs in order to deliver marketing messages, and often to respond to corporate crises. For instance, following a consumer backlash during the launch of its Masala Dosa Brioche breakfast in India, McDonald's employed well-known food influencers to act as social advocates of the new offering in order to turn consumers' sentiment around (Firstpost, 2017). Such practices have put SMIs in a prominent position in modern-day marketing. While marketers strive to employ SMIs in their campaigns, scholarly evidence in the domain is still sparse.

Extant research shows that recommendations from SMIs enhance consumers' positive perceptions about a brand and consequent purchase intentions (Lu, Chang, \& Chang, 2014), especially when influencers are able to build a connection with consumers (Hwang \& Zhang, 
2018; Lee \& Watkins, 2016) and are perceived as credible (Djafarova \& Rushworth, 2017). SMIs gain credibility and popularity by forging communal relationships based on collaboration and the sharing of mutual benefits with followers (Cocker \& Cronin, 2017). Taken together, existing studies suggest a positive impact of SMIs' presence on consumers' perception, thereby indicating that brands benefit from investing into influencer marketing. In practice, consumers are increasingly aware of influencers' affiliation to brands, as evidenced by recent industry reports (Statista, 2018). Crucially, research shows that consumers are rarely passive receivers of brands' persuasive attempts, but rather actively resist seemingly manipulative brand communication efforts (e.g., Kapitan \& Silvera, 2016; Liljander, Gummerus, \& Söderlund, 2015; Singh, Crisafulli, \& Quamina, 2019a). Similar in function to company employees, SMIs might be perceived to act in the interests of the brand rather than in the interest of consumers (Liljander et al., 2015). When SMIs support a brand in crisis, consumers could be suspicious of the brand's crisis response and perceive it as a manipulative attempt to persuade consumers into believing that the crisis is not as severe as it seems (Kapitan \& Silvera, 2016). Notably, as negative events, crises are likely to trigger attributions of negative motives of the brand and play a critical role in abetting consumer skepticism (Klein \& Dawar, 2004). The practice of involving an influencer in crisis communications can therefore be interpreted as a manipulative attempt of the brand, and thus potentially damage its corporate reputation. Despite corporate brands' penchant for adopting influencer marketing, the role of SMIs in shaping consumers' perception of a brand's crisis response and corporate reputation has not been addressed so far, and represents the focus of our study.

A pertinent theoretical lens explaining the potential downsides associated with the employment of SMIs in corporate crisis communications is the theory of persuasion knowledge (Friestad \& Wright, 1994). Drawing on the above theory, we posit and 
demonstrate that consumers are suspicious of crisis response messages where SMIs, who are typically affiliated to and sponsored by the corporate brand, are present. Our studies show that the presence of SMIs in crisis communications enhances persuasion knowledge access and leads to inferences of the corporate brand as being manipulative in its intent. Inferences of manipulative intent, in turn, lower perceived brand trustworthiness (Guo \& Main, 2012; Xie \& Peng, 2009), which subsequently influences corporate reputation (Doney \& Cannon, 1997; Walsh, Mitchell, Jackson, \& Beatty, 2009). Crucially, as consumers seek to assign accountability for crises, the crisis context acts as a catalyst in enhancing persuasion knowledge access and in raising suspicion, which results in higher manipulative intent inferences.

Further, we explore the conditions under which consumers' negative reactions to SMIs, and invariably to the corporate brand partnering with the SMI, are minimized. In particular, we propose and demonstrate that the brand benefits when altruistic, values-driven motives behind the influencer-brand partnership, are made salient (DeCarlo, 2005; Vlacos, Tsamakos, Vrechopoulos, \& Avramidis, 2009). We show that disclosing to consumers that the influencer is not being paid additional commissions for responding to the crisis lowers consumer inferences of manipulative intent associated with the influencer's presence.

Our study makes several notable contributions to theory. The research advances literature on crisis management by examining, for the first time, the interplay between crisis response strategies and influencers' presence. In doing so, we explain the psychological process underlying consumer responses to different stakeholders involved in crisis communications. We show that consumers are active thinkers who evaluate and vigorously resist persuasive attempts of brands. Persuasion knowledge and motive attributions, in fact, play a pivotal role in influencing the efficacy of crisis communications. Further, we extend research on influencer marketing by identifying downsides associated with the employment of SMIs in 
crisis communications. By showing that heightened manipulative intent inferences are elicited by the affiliation of SMIs to a brand's crisis response, our study suggests that influencer marketing might not always be as effective as claimed by previous research. We further establish strategies to offset the downsides associated with employment of SMIs in crisis management efforts. Consumers seem to resist crisis response messages reinforced by SMIs, as influencers are perceived to be driven by strategic, profit-seeking motives. Crisis response messages, however, are advantageous if the values-driven motives behind the influencer-brand partnership are actively communicated. Finally, we contribute to the literature on corporate crisis responses by demonstrating that manipulative intent and brand trustworthiness act as important mechanisms that shape consumers' post-crisis perception of corporate reputation. In addition to the theoretical contributions, our findings have important implications for SMI marketing and corporate crisis management.

\section{Conceptual background and hypotheses development}

Corporate crises denote "unexpected events that threaten a brand's perceived ability to deliver expected benefits" (Dutta \& Pullig, 2011, p. 1281). As negative events, crises can embody signals of the 'bad' character of a brand, putting its reputation at stake (e.g., Connelly, Certo, Ireland, \& Reutzel, 2011; Rao, Qu, \& Ruekert, 1999; Spence, 1973). Incentivized by the need to maintain good reputation in the marketplace while retaining the customer base, companies typically employ a response strategy following a crisis (Coombs, 2010). In the well-established Situational Crisis Communication Theory, Coombs (1995; 1998; 2007) distinguishes between four main crisis response strategies - diminish, deny, rebuild, and bolster. While diminish and deny responses aim to convince the public that a crisis does not exist, rebuild response seeks to improve goodwill by offering some form of compensation or atonement, and bolster response attempts to minimize the offensiveness of the crisis by ingratiating on the company's existing goodwill. 
Notwithstanding the breadth of past research examining crisis response strategies, evidence on the efficacy of response strategies is mostly inconsistent. For instance, some studies argue that denial is an effective response strategy in crises where the integrity of the brand is at stake (e.g., Ferrin, Kim, Cooper, \& Dirks, 2007; Kim, Ferrin, Cooper, \& Dirks, 2004), but other scholars do not corroborate such finding (e.g., Dutta \& Pullig, 2011).

Similarly, it is suggested that response strategies should be matched with the crisis type (e.g., Dutta \& Pullig, 2011; Singh, Crisafulli, \& Quamina, 2019b). Other studies, however, contend that the matching hypothesis does not hold among low involvement consumers (e.g., Claeys \& Cauberghe, 2014; Claeys, Cauberghe, \& Vyncke, 2010).

The above evidence, while insightful, accounts for circumstances where brands alone respond to crises. In practice, brands increasingly partner with brand representatives such as celebrities or influencers, and such partnerships influence decisions concerning crisis communications (Carrillat, d'Astous, \& Lazure, 2013; Thomas \& Fowler, 2016). Crucially, much of the previously studied crisis responses, such as diminish, rebuild or deny, imply that brands revert to crisis communications in order to address any wrongdoings, yet without aiming for additional reputational gain (Dutta \& Pullig, 2011). While seeking to offset a crisis event, companies might also remind consumers of the brand's goodwill, consistent with a bolstering response strategy that Coombs $(1995 ; 2007)$ refers to as ingratiation. As a bolster response, ingratiation is beneficial in enabling the brand to cost-effectively leverage reputational gains while addressing the crisis (Coombs, 2007). Given its pivotal role in corporate reputation management, we focus on ingratiation as a crisis response strategy and its interplay with the influencer's presence, in explaining consumer post-crisis perceptions toward the brand.

\subsection{Social media influencers in crisis communications}


Social media influencers (SMIs) typically include individuals who have gained popularity through online blogging, video-blogging, or social networking sites, and are recognized to have social influence due to their large number of followers/subscribers (Jin \& Phua, 2014). Currently, research on SMIs is still incipient, as shown in our review of key studies in the domain (see Table 1). Studies adopting an organizational perspective on the phenomenon examine current practices concerning managerial decisions around the employment of SMIs in brand communications (e.g., Uzunoğlu \& Kip, 2014). Other studies following a consumer perspective, albeit limited, highlight the beneficial effects of influencers on brands. For instance, evidence suggests that SMIs are able to encourage the purchase decisions of female consumers, more than celebrity endorsers (Djafarova \& Rushworth, 2017). Further, bloggers' recommendations are shown to enhance positive consumer attitudes and purchase intentions when perceived as trustworthy and useful (Hsu, Lin, \& Chiang, 2013; Lee \& Watkins, 2016).

$$
<\text { insert Table 1> }
$$

Research investigating the downsides of influencer marketing is, nonetheless, scarce. Emerging evidence shows that the disclosure of sponsorship agreements behind SMIs' online postings activates followers' persuasion knowledge which, in turn, enhances negative word of mouth (Hwang \& Zhang, 2018). Such negative effects seem to diminish when followers feel that they are in a valuable relationship with the influencer (Hwang \& Zhang, 2018) and when the attributes of products recommended by SMIs can be easily verified (Lu et al., 2014).

We posit that the downsides of influencer marketing become evident when the brand leverages on SMIs' presence in order to gain support in crisis management. Due to the amplified exposure to SMIs, consumers are knowledgeable of SMIs' affiliation to brands (Kapitan \& Silvera, 2016). Hence, when evaluating crisis responses that involve SMIs, 
consumers might suspect that the response is a manipulative attempt by the brand to persuade them into believing that the crisis is less serious, or detrimental, than it might seem. Suspicion of manipulative intent might, in turn, negatively affect corporate brand perceptions. Based on above theorizing, we develop our research hypotheses, as detailed in the sections below.

\subsection{Consumer perceptions of crisis response source}

Extant evidence on the efficacy of ingratiation as a crisis response strategy is limited to a handful of studies showing mixed results. Some studies support the efficacy of ingratiation following crises. For instance, examining a crisis with a university sport club, Brown and Billings (2013) show that a university's heavy use of ingratiation messages encourages fans to post supportive statements and to unite themselves with other members of the fan base. Similarly, in an experimental study of a product-harm crisis, Dardis and Haigh (2009) show that ingratiation leads to higher reputational perceptions, as compared to denial or corrective responses such as rebuild. In addition, addressing the harmful effects of crises via ingratiation is found to enhance perceptions of organization-public relationship and corporate social responsibility (Haigh \& Brubaker, 2010). Favorable responses to accommodative organizational responses of ingratiation and apology has been associated with the elicitation of sympathy in less severe crises (Jin, 2014). There is, however, contrasting evidence showing that ingratiation following severe environmental crises negatively influences consumer trust, attitudes toward the company, and perceived reputation, akin to a no response strategy (Park, 2017). Further, ingratiation appears to be ineffective when used by celebrity endorsers seeking to distance themselves from the endorsed brand responsible for the wrongdoing (Thomas \& Fowler, 2016). The above study finds ingratiation to be as effective as a diminish response in mitigating the negative effect of a brand transgression. 
In organizational settings, ingratiation is shown to be an important means for employees to develop social capital with their supervisors (Adler \& Kwon, 2002; Westphal \& Stern, 2007). Social capital helps employees to build long-lasting relationships. Ingratiation efforts convey how employees are valued and admired, leading to the formation of supervisors' positive opinions (Schriesheim, Castro, \& Yammarino, 2000), liking, and favorable performance assessments (Wayne \& Ferris, 1990; Wayne \& Liden, 1995). Consistent with the above background, there is evidence to suggest that ingratiation can be a credible brand communication tactic under certain circumstances. In the event of crises, brands that capitalize on a history of goodwill and positive past encounters with consumers could employ ingratiation in order to convey their dominance and admiration in the marketplace. Ingratiation would thus appear credible, as underpinned by good past behavior of the corporate brand. In line with persuasion knowledge theory, credible marketing tactics lower access to persuasion knowledge, and accordingly, minimize inferences of manipulative intent (Isaac \& Grayson, 2017). Accordingly, ingratiation could enhance perceived brand trustworthiness and lower manipulative intent inferences when rendered by the brand alone, and thus perceived as a credible tactic. Thus:

H1a-b: Following a corporate crisis, ingratiation response (vs no response) leads to (a) higher perceptions of brand trustworthiness, and (b) lower inferences of manipulative intent if the SMI is absent.

The effect of ingratiation response strategy, however, could be undermined by the presence of a social media influencer supporting the brand's crisis management efforts. Extant research on influencer marketing makes an implicit assumption that consumers are passive receivers of company and influencers' messages, accepting such messages at face value. Such an assumption, nonetheless, overlooks evidence from social psychology (e.g., DeCarlo, 2005; Kirmani \& Zhu, 2007) and service research (e.g., Antonetti, Crisafulli, \& 
Maklan, 2018) showing that consumers are active (rather than passive) thinkers and resist highly persuasive attempts of companies and of their representatives. As postulated by persuasion knowledge theory (Friestad \& Wright, 1994), individuals possess persuasion knowledge, which denotes 'knowledge about the tactics used in persuasion attempts' (p. 1). Such knowledge contains beliefs about the persuasion goals of marketers, the tactics used to achieve persuasive goals as well as the tactics available for coping with persuasive attempts (Friestad \& Wright, 1994). A similar set of beliefs performs "schema-like functions", for instance by directing consumer attention toward particular features of a message and by enabling consumers to anticipate the effects of a certain message (Friestad \& Wright, 1994, p. 3). When accessed, persuasion knowledge enables consumers to recognize and resist persuasive attempts, including messages from salespeople and/or advertisements (e.g., DeCarlo, 2005; Kirmani \& Zhu, 2007).

The activation of persuasion knowledge enhances suspicion about the ulterior motives of the brand (or its representatives), thus leading to inferences of manipulative intent (Campbell, 1995; Isaac \& Grayson, 2017). Such inferences are found to diminish the persuasiveness of the company message (Campbell \& Kirmani, 2000) and perceived trustworthiness (Guo \& Main, 2012). Consistent with persuasion knowledge theory, we argue that consumers are active thinkers; due to persuasion knowledge, they can recognize and resist the persuasive attempts of brands and influencers, as manifested in their perceptions and inferences about the brand's intent.

Like salespeople, SMIs can be seen as acting out of their personal financial motives, and in the interests of the brand. Prior research on celebrity endorsers suggests that celebrities endorse brands for two main reasons; their true beliefs in the brand, or financial gains accruing from the endorsement (Sparkman, 1982). When financial gains are perceived to be the key driver of a celebrity's actions, consumers infer exploitation and manipulative intent 
(Moore, Mowen, \& Reardon, 1994; Sparkman, 1982). Similar to celebrities and as brand's representatives, SMIs can be perceived to endorse the brand for self-interests, especially in the context of crisis communications. Consumer awareness of the profit-making motivations behind SMIs' involvement can render the ingratiation message into a low credibility tactic. Consistent with persuasion knowledge theory, low credibility tactics enhance persuasion knowledge access and consequent skepticism (Isaac \& Grayson, 2017). It follows that the persuasiveness of influencers' communications diminishes, and inferences of the brand's manipulative intent increase (Isaac \& Grayson, 2017).

In line with the above logic, we argue that the ingratiation response strategy from the brand might lose its advantage when the SMI is present and supports the brand in its crisis communication efforts. Consumers might question the source of crisis response and construe the influencer's involvement as the brand's manipulative attempt to persuade them into believing that the crisis is less serious than it appears. Accordingly, we hypothesize:

H2a-b: Following a corporate crisis, ingratiation response leads to (a) brand trustworthiness and (b) manipulative intent inferences which are comparable to a no response strategy, if the SMI is present.

Resistance to persuasive attempts is found to diminish the persuasive bearing of the message (Campbell \& Kirmani, 2000), favorable attitudes toward the salesperson (DeCarlo, 2005), and perceived trustworthiness (Guo \& Main, 2012), while augmenting inferences of manipulative intent (Campbell, 1995; Kirmani \& Zhu, 2007). Invariably, inferences of manipulative intent triggered by persuasion knowledge activation can accrue negative feelings toward the brand (Fein \& Hilton, 1994), and influence corporate reputation perceptions. As a precursor of reputation, brand trustworthiness is expected to influence reputation ratings (Park, Lee, \& Kim, 2014; Sujan, Bettman, \& Sujan, 1986). 
Building on prior findings from persuasion knowledge literature, we argue that when the SMI is present and an ingratiation response strategy is employed, a negative spiral is created whereby heightened manipulative intent inferences and lowered perceived trustworthiness impact corporate reputation. When the SMI is absent, by contrast, corporate reputation is likely to be 'protected', given that the ingratiation response strategy lowers manipulative intent inferences and fosters brand trustworthiness, both factors ultimately positively influencing corporate reputation. An indirect effect of ingratiation response on corporate reputation through manipulative intent and perceived trustworthiness is, therefore, expected when the SMI is absent. No such indirect effect is, however, expected when the SMI is present and persuasion knowledge access is enhanced. Accordingly, we hypothesize:

H3-4: Following a corporate crisis, manipulative intent and perceived trustworthiness serially mediate the effect of ingratiation response on corporate reputation when the SMI is absent. The serial mediation of manipulative intent and perceived trustworthiness is not observed when the SMI is present.

\subsection{Improving perceptions about the crisis response source}

The above discussion points to potential downsides associated with the employment of SMIs in crisis communications. For the managers insights on how to minimize the effects of such drawbacks is highly relevant. To investigate the above, we consider a strategy that could offset the downside of employing SMIs in crisis communications. Specifically, we test whether the active attempt to communicate the altruistic, values-driven motives behind the SMI-brand partnership can lower inferences of manipulative intent.

A key assumption of persuasion knowledge research is that individuals make attributions about the motives of the agent delivering the persuasive message (Campbell, 1995). The process of making attributions helps consumers to establish the rationale behind agents' behaviors, and to assign responsibility (Heider, 1958; Weiner, 1985). Attributions vary in 
nature, with customer-oriented attributions typically resulting in inferences of altruistic, values-driven motives, and suspicion-oriented attributions leading to inferences of ulterior, profit-seeking motives (DeCarlo, 2005; Kirmani \& Zhu, 2007). Evidence suggests that inferences of ulterior motives make consumers suspicious of companies' actions, including personal selling (DeCarlo, 2005), CSR, and more generally socially responsible initiatives (Vlacos et al., 2009; Yoon, Gürhan-Canli, \& Schwarz, 2006).

Notably, evidence from persuasion research on personal selling shows that, in circumstances where the suspicion of ulterior motives is salient (e.g., personal selling), a salesperson's selling (negative) motive can only be discounted via an attribution process that disconfirms the prominent "selling" expectation (DeCarlo, 2005, p. 239). For individuals to disconfirm ulterior motives, information about the salesperson's altruism should be communicated. Such information helps consumers to generate positive attributions about the true intent of the salesperson (DeCarlo, 2005; Fein, Hilton, \& Miller, 1990). In this respect, evidence shows that a weak (vs strong) sales message enhances consumers' positive attitudes toward the salesperson, even if suspicion of ulterior motives is salient given the selling context (DeCarlo, 2005). While strong sales messages are cognitively congruent with the initial suspicion-oriented attributions and thus fit consumers' cognitive schema (Sujan et al., 1986), a weak sales message can disrupt the cognitive schema and disconfirm existing negative expectations, thereby leading to positive evaluations about the message source (Eagly, Wood, \& Chaiken, 1978). In other words, information that counters existing negative expectations and cognitive schema are likely to trigger customer-oriented attributions, resulting in positive perceptions.

Building on persuasion knowledge along with attribution theory (Heider, 1958; Weiner, 1985), we argue that information regarding the altruistic, values-driven motives of the SMI and of the brand could mitigate suspicion about the brand's motives for using SMIs in crisis 
communications. Accordingly, negative reactions toward the ingratiation response could be lowered (Friestad \& Wright, 1994; Szykman, Bloom, \& Blazing, 2004). In sum, the process of conveying the values-driven motives of the crisis response source (i.e. the SMI and the brand) might offset the downside associated with the employment of SMIs in crisis communications, which we postulated earlier.

Such argument is also consistent with past research on ingratiation showing that otherenhancement ingratiation behavior (i.e. highlighting the benefits to others) tends to be more effective than self-enhancement ingratiation (i.e. highlighting the benefits for the self) (Gordon, 1996; Higgins, Judge, \& Ferris, 2003), with the former type being least likely to be perceived as manipulative by the target (Koopman, Matta, Scott, \& Conlon, 2015; Vonk, 2002). In the context of our study, the brand's response might be conceived as a form of selfenhancing ingratiation, whereby the brand bolsters its past good actions. However, the act of communicating positive motives might counter self-enhancement attempts and be rather perceived as other-enhancing ingratiation, as the brand and influencer seek to convey how their actions are driven by customer-focused, altruistic motives. Accordingly, we hypothesize:

H5: Following a corporate crisis, the effect of ingratiation response on inferences of manipulative intent is stronger (weaker) when values-driven motives of the SMI and brand are high (vs medium or low).

H6: The mediated effect of ingratiation response on perceived trustworthiness is stronger (weaker) when values-driven motives of the SMI and brand are high (vs medium or low).

\section{Method}

\subsection{Overview of the empirical research}

Figure 1 presents the conceptual model for our research. To test the model, we conducted two experiments where participants were asked to evaluate a corporate crisis scenario and 
consequent crisis response from the brand alone, or from the brand and the influencer. The use of scenario-based experiments is consistent with prior research on corporate crisis responses (e.g., Crijns, Cauberghe, Hudders, \& Claeys, 2017; Dutta \& Pullig, 2001; Singh et al., 2019b). Study 1 examines potential downsides associated with crisis communications involving a social media influencer, and underlying psychological mechanisms (H1a-b; H2ab; H3-H4). We posit that SMIs are perceived by consumers as a persuasive source, indicative of the brand's manipulative attempt, and thus lower the positive effect of ingratiation response. Study 2 examines whether the potential downsides associated with the employment of SMIs in crisis communications, as revealed in Study 1, can be mitigated by conveying altruistic, values-driven motives behind the brand-influencer partnership. Our argument is that the effectiveness of ingratiation response increases (vs no response) when the influencer and the brand convey altruistic and values-driven motives that are salient to consumers (H5H6). Below we provide an overview of the research design and analysis for each study, along with related results.

$$
\text { <insert Figure 1> }
$$

\subsection{Study 1}

Design and sample

We conducted a 2 (crisis response: ingratiation vs no response) x 2 (crisis response source: SMI vs no SMI) between-subjects experiment. The sample comprised of 254 UK residents recruited from a large online consumer panel, Prolific Academic. Four responses were removed as participants failed the attention checks, thus leaving 250 valid responses for analysis, consisting of $72 \%$ females. Different age groups were represented: $26 \% 18$ to 24 years old, $42 \% 25$ to $34,22 \% 35$ to 44 , and $10 \%$ were 45 years or older.

\section{Stimuli}


We administered an online survey to participants. It included experimental scenarios of a corporate brand crisis and consequent response. To develop the scenarios, we conducted secondary research and two pre-tests. Based on secondary research, a list of corporate brands that faced crises, along with a list of well-known SMIs, were developed. In pre-test $1(n=55)$, based on high familiarity and positive attitudes, a leading beauty influencer with $11 \mathrm{~m}$ YouTube subscribers and a market-leading toothpaste brand were selected as influencer and corporate brand, respectively. In pre-test $2(n=22)$, perceived fit between the brand and the influencer was confirmed. We developed the scenarios based on real-life crises, following the approach used in prior research (Cleeren, Van Heerde, \& Dekimpe, 2013; Hsu \& Lawrence, 2016; Liu \& Shankar, 2015). The crisis was about a toothpaste ingredient potentially leading to health risks. We designed a fictitious crisis response consistent with the literature (e.g., Dutta \& Pullig, 2011; Liu, Austin, \& Jin, 2011).

We manipulated the crisis response following Coombs' (2007) typology. In the No response condition, the brand did not provide a response following the crisis. In the ingratiation response condition, the brand sought to abate the detrimental effects of the crisis by ingratiating on its goodwill. Accordingly, an excerpt from the scenario reads as follows: "We remind our customers that Brand $X$ was ranked in top 100 fast-moving consumer brands by Interbrand in 2018, and that is evidence of our past and continuous good work as a brand."

We manipulated crisis response source by showing that the SMI was present and echoed the brand's response to the crisis, or absent (the brand responded alone). We developed the influencer's post based on secondary research on the textual and visual content of influencers' posts on publicly available social media platforms, following Mardon, Molesworth and Grigore (2018). The post was written to match the personality of the 
influencer as well as the informal and friendly tone that appears to characterize most influencers' online posts. Scenarios for the above conditions are in Appendix A.

As part of the manipulation checks, we asked participants to identify the nature of the crisis response as 'an attempt to remind consumers of the past good works of the brand' $\left(\mathrm{M}_{n o}\right.$ response $\left.=3.03, \mathrm{M}_{\text {ingratiation }}=5.94, t(166)=11.90, p=.000\right)$, and 'the brand ignored the news article' $\left(\mathrm{M}_{\text {no response }}=5.73, \mathrm{M}_{\text {ingratiation }}=2.75, t(203)=12.95, p=.000\right)$. For SMI presence, participants were asked if 'the brand responded with the help of an influencer who supported the brand' $\left(\mathrm{M}_{n o S M I}=2.21, \mathrm{M}_{\text {SMI present }}=5.79, t(189)=19.51, p=.000\right)$, or 'the brand responded alone' $\left(\mathrm{M}_{n o}\right.$ SMI $=3.83, \mathrm{M}_{S M I}$ present $\left.=2.42, t(183)=5.02, p=.000\right)$. Overall, the results showed that crisis response and crisis response source were successfully manipulated. Realism and clarity checks confirmed that the scenarios were understandable $(M=4.87)$, believable $(M=5.06)$ and realistic $(M=5.09)$. Mean values were greater than the scale midpoint of $4(p=.000)$, with no differences across conditions.

\section{Measures}

We adopted and contextualized established multi-item scales for the study (see Table 2). Five items from Campbell (1995) for manipulative intent, five items from Xie and Peng (2009) for perceived brand trustworthiness encompassing perceived competence, benevolence and honesty, and three items from Doney and Cannon (1997) for corporate reputation, all on a 7 -point Likert-type scale anchored at $1=$ strongly disagree and $7=$ strongly agree. Further, measures of pre-existing attitudes toward the brand, perceived credibility of the SMI, attitudes and familiarity of the influencer, were included as covariates in the analysis (e.g., Colliander \& Dahlén, 2011; Simmons \& Becker-Olsen, 2006).

The scales performed adequately in terms of reliability with loadings greater than .7 on the intended constructs (Bagozzi \& Yi, 1989). One manipulative intent item and one corporate reputation item yielded low loadings (below .6) and were removed from further analysis, 
following Hair, Hult, Ringle, and Sarstedt (2016). Average Variance Extracted (AVE) and Composite Reliability (CR) estimates were above the established thresholds of .5 and .7, respectively (Bollen \& Lennox, 1991), confirming internal consistency. Discriminant validity was established through the Fornell-Larcker criterion (Fornell \& Larcker, 1981). All measures, sources, and standardized loadings are presented in Table 2. Correlations between our conceptual constructs and results from discriminant validity checks are reported in Appendices C and D.

\section{$<$ insert Table 2>}

\section{Analysis and results}

The purpose of Study 1 was twofold: first, to assess the interaction between crisis response and crisis response source on perceived trustworthiness and manipulative intent (H1a-b; H2ab), and second, to explain the psychological mechanism underlying the effect of crisis response on corporate reputation $(\mathrm{H} 3-\mathrm{H} 4)$. We conducted MANOVA with the three dimensions of perceived trustworthiness and manipulative intent as dependent variables, and the experimental factors as independent variables. We included brand attitudes, SMI attitude, credibility, and familiarity as covariates. None of the covariates showed a significant effect on our dependent variables, hence were removed from further analysis.

The results showed a significant main effect of ingratiation response on perceived competence $(F(1,201)=6.21, p<.05)$, honesty $(F(1,201)=19.47, p<.01)$, benevolence $(F(1,201)=31.93, p<.01)$, and manipulative intent $(F(1,201)=12.90, p<.01)$. In particular, perceived trustworthiness was found to be significantly higher following an ingratiation response $\left(\mathrm{M}_{\text {Competence }}=4.23 ; \mathrm{M}_{\text {Honesty }}=4.12 ; \mathrm{M}_{\text {Benevolence }}=4.01\right)$ than no response $\left(\mathrm{M}_{\text {Competence }}=3.73 ; \mathrm{M}_{\text {Honesty }}=3.23 ; \mathrm{M}_{\text {Benevolence }}=2.83\right)$. Inferences of manipulative intent, by contrast, were significantly higher in the no response condition $(M=4.71)$ when compared with the ingratiation response condition $(\mathrm{M}=4.07)$. SMI presence did not have a significant 
main effect on perceived competence $(F(1,201)=2.09, p>.05)$, honesty $(F(1,201)=0.63, p$ $>.05)$, benevolence $(F(1,201)=2.27, p>.05)$, and manipulative intent $(F(1,201)=1.31, p$ $>.05)$. The above results confirmed that consumers reacted more favorably with an ingratiation response strategy, as compared with no response; this was a necessary step toward testing the interaction hypothesized in our main hypotheses.

We found evidence of a significant interaction effect between crisis response and crisis response source on competence $(F(1,201)=8.17, p<.01)$, honesty $(F(1,201)=4.52, p<$ $.05)$ and benevolence $(F(1,201)=5.24, p<.05)$. When the SMI was absent, consumers exhibited more favorable perceptions of trustworthiness toward the brand using ingratiation response, than toward the brand providing no response to the crisis (Competence: $\mathrm{M}_{\text {No response }}$ $=3.29, \mathrm{M}_{\text {ingratiation }}=4.38, t(97)=3.60 ;$ Honesty: $\mathrm{M}_{\text {no response }}=2.94, \mathrm{M}_{\text {ingratiation }}=4.26, t(99)=$ 4.88; Benevolence: $\left.\mathrm{M}_{\text {no response }}=2.43, \mathrm{M}_{\text {ingratiation }}=4.10 ; t(99)=6.11, p<.01\right)$. Further, manipulative intent inferences were lower if the brand alone used ingratiation, without the SMI supporting the brand's stance $\left(\mathrm{M}_{n o}\right.$ response $=4.73, \mathrm{M}_{\text {ingratiation }}=3.84, t(99)=3.42, p<$ $.01)$. However, when the SMI was present, the above effects for honesty $\left(\mathrm{M}_{\text {no response }}=3.52\right.$, $\left.\mathrm{M}_{\text {ingratiation }}=3.99, t(102)=1.54, p>.05\right)$ and manipulative intent $\left(\mathrm{M}_{n o}\right.$ response $=4.69$, $\left.\mathrm{M}_{\text {ingratiation }}=4.29, t(102)=1.61, p>.05\right)$ did not hold, as ingratiation response performed similar to the no response strategy. When the SMI was present, the positive effect of ingratiation on competence was reversed, though not significant $\left(\mathrm{M}_{\text {no response }}=4.16\right.$, $\left.\mathrm{M}_{\text {ingratiation }}=4.09, t(102)=0.27, p>.05\right)$. Overall, the results confirmed H1a-b and H2a-b (see Appendix E).

To test for the (serial) mediation of manipulative intent and perceived trustworthiness, we ran a conditional effect analysis, set at 10,000 resamples and estimated confidence intervals (Model 6 in PROCESS; Hayes, 2018). The average of the items for each construct was used for the analysis, and we coded the No response and Response conditions as 0 and 1 , 
respectively. The analyses were conducted for two groups; one represented the No SMI condition, and the other represented the SMI condition. Consistent with H3-H4, manipulative intent and perceived trustworthiness accounted for a significant portion of variance explaining corporate reputation. Conditional to our proposed model, these two variables sequentially mediated the relationship between crisis response and corporate reputation when the SMI was absent $(95 \%, \mathrm{CI}=.00$ to .14$)$. Such serial mediation however was not significant when the SMI was present $(95 \%, \mathrm{CI}=-.00$ to .16$)$. Manipulative intent diminished honesty to the extent that honesty did not engender positive corporate reputation perceptions (coefficient: -.04). To check for revere mediation, we conducted the same analysis by including the mediators in reverse order (trustworthiness first and manipulative intent second) consistent with reverse mediation testing procedure (e.g., Bellezza, Paharia, \& Keinan, 2017). The indirect effect was not significant when the mediators were reversed, in both the No SMI condition $(.03 ; 95 \% \mathrm{CI}=-.02$ to .97$)$ and the SMI condition $(-.003 ; 95 \% \mathrm{CI}$ $=-.04$ to .03 ). We also inverted the order of the dependent and mediating variables (e.g., Lemmer \& Gollwirtzer, 2017). The reversed indirect effects were not statistically significant, hence alternative models were ruled out ${ }^{1}$. Table 3 summarizes the results of the indirect effects.

\section{$<$ insert Table 3>}

In conclusion, Study 1 provide evidence of some downsides associated with the employment of SMIs in crisis communications. The findings suggest that consumers overwhelmingly interpret the contribution of an influencer in crisis communications as a

\footnotetext{
${ }^{1}$ Crisis response $\rightarrow$ Competence $\rightarrow$ Honesty $\rightarrow$ Benevolence $\rightarrow$ Corporate reputation $\rightarrow$ Manipulative Intent (-.01; 95\% CI $=-.04$ to .02). Crisis response $\rightarrow$ Honesty $\rightarrow$ Benevolence $\rightarrow$ Corporate reputation $\rightarrow$ Manipulative Intent $\rightarrow$ Competence $(.01 ; 95 \% \mathrm{CI}=-.00$ to .04$)$. Crisis response $\rightarrow$ Competence $\rightarrow$ Benevolence $\rightarrow$ Corporate reputation $\rightarrow$ Manipulative Intent $\rightarrow$ Honesty $(.005 ; 95 \% \mathrm{CI}=-.00$ to .02$)$. Crisis response $\rightarrow$ Competence $\rightarrow$ Honesty $\rightarrow$ Corporate reputation $\rightarrow$ Manipulative Intent $\rightarrow$ Benevolence (.02; 95\% CI $=-.01$ to .07). Crisis response $\rightarrow$ Competence $\rightarrow$ Honesty $\rightarrow$ Corporate reputation $\rightarrow$ Manipulative Intent $\rightarrow$ Benevolence $(.02 ; 95 \% \mathrm{CI}=-.01$ to .07$)$.
} 
persuasive tactic of the brand. The brand's attempt to partner with the influencer in its crisis communication efforts is perceived as manipulative. In Study 2, we seek to understand whether crisis communications wherein the altruistic, values-driven motives of the brand and of the SMI are made salient, can contribute toward offsetting the drawbacks associated with influencer's presence identified in Study 1.

\subsection{Study 2}

\section{Research design and sample}

We conducted a 2 (crisis response: ingratiation vs no response) x 2 (crisis response source motives: SMI and brand with values-driven motives vs no SMI) between-subjects experiment. Using the same consumer panel and procedures as in Study 1, we obtained 172 responses. Six responses were removed as participants failed the attention checks, thus leaving 166 valid responses for analysis, consisting of 74\% females. Different age groups were represented: $24 \% 18$ to 24 years old, $45 \% 25$ to $34,16 \% 35$ to 44 , and $15 \%$ were 45 years or older.

\section{Stimuli}

Similar to Study 1, participants evaluated a scenario of a crisis affecting a beauty brand and a subsequent crisis response (or lack thereof). The manipulation of crisis response was consistent with Study 1. We developed the manipulation of crisis response source motives following DeCarlo (2005). Accordingly, in the SMI and brand with values-driven motives condition, participants read an online post whereby the SMI warned followers of the problem with the product stating that scientists were looking into any possible harmful consequences. Next, participants read that 'the brand did not pay any commission to the influencer for posting such a warning message. The influencer warned her followers as she cares about their health'. The stimuli are included in Appendix B. 
Results showed that ingratiation response was successfully manipulated ( $\mathrm{M}_{\text {no response }}=$ $\left.3.54, \mathrm{M}_{\text {ingratiation }}=5.55, t(147)=7.45, p=.000\right)$. For the motive manipulation, participants were asked if 'an influencer responded to the scandal' $\left(\mathrm{M}_{n o ~ S M I}=3.80, \mathrm{M}_{\text {brand and SMI values-driven }}\right.$ motives $=5.51, t(163)=5.88, p=.000)$, 'the brand paid no commission to the influencer' $\left(\mathrm{M}_{n o}\right.$ $\left.S M I=3.46, \mathrm{M}_{\text {brand and SMI values-driven motives }}=5.64, t(163)=8.69, p=.000\right)$ and 'the influencer and the brand had good intentions in mind (i.e. care about the health of their followers)' $\left(\mathrm{M}_{\text {no }}{ }_{S M I}=\right.$ $\left.3.65, \mathrm{M}_{\text {brand and SMI values-driven motives }}=4.52, t(163)=3.20, p=.002\right)$. Realism and clarity checks confirmed that the scenarios were understandable $(M=4.93)$, believable $(M=5.21)$ and realistic $(\mathrm{M}=5.19)$ (all scores above the scale mid-point of .4, $p=.000)$.

\section{Measures}

The measures adopted were identical to those in Study 1. A measure of values-driven motives (Vlacos et al., 2009) was added in Study 2. All measures performed satisfactorily with respect to Cronbach's Alpha, CR, AVE, and discriminant validity (see Table 2 and Appendix C).

\section{Analysis and results}

Study 2 demonstrates whether the downsides associated with the influencer's presence in crisis communications can be addressed by turning the altruistic, values-driven motives behind the influencer-brand partnership salient, that is, known to consumers (H5-H6). We conducted MANOVA using SMI credibility as a covariate (all other covariates showed no effect on the dependent variables and were, therefore, excluded). Results showed a significant difference between the crisis response conditions in terms of competence $(F(1$, $121)=17.60, p<.01)$, honesty $(F(1,121)=28.64, p<.01)$, benevolence $(F(1,121)=42.18$, $p<.01)$, and manipulative intent $(F(1,121)=16.20, p<.01)$. There was no significant difference in terms of the above scores between the No SMI and the SMI with values-driven motives conditions, except for competence $(F(1,121)=4.79, p<.05)$. 
As expected, we found a significant interaction effect between crisis response and crisis response source motives on benevolence $(F(1,121)=9.30, p<.05)$, and marginally on competence $(F(1,121)=3.46, p<.10)$, honesty $(F(1,121)=3.71, p<.10)$ and manipulative intent $(F(1,121)=3.58, p<.10)$. When the SMI was absent, participants exhibited significantly higher trustworthiness toward the brand using ingratiation response (Competence: $\mathrm{M}_{n o}$ response $=4.18, \mathrm{M}_{\text {ingratiation }}=6.27, t(81)=4.69 ;$ Honesty: $\mathrm{M}_{\text {no response }}=2.52$, $\mathrm{M}_{\text {ingratiation }}=4.40, t(81)=6.48 ;$ Benevolence: $\mathrm{M}_{\text {no response }}=2.15, \mathrm{M}_{\text {ingratiation }}=4.34, t(81)=$ 7.26; $p<.01)$. As expected, consumers reported lower inferences of manipulative intent when the brand uses ingratiation and there was no SMI supporting the brand's stance $\left(\mathrm{M}_{n o}\right.$ response $\left.=5.01, \mathrm{M}_{\text {ingratiation }}=3.93, t(81)=3.79, p<.01\right)$. The above effects on competence $\left(\mathrm{M}_{\text {no response }}=5.58, \mathrm{M}_{\text {ingratiation }}=6.31, t(80)=1.77, p>.05\right)$ and manipulative intent $\left(\mathrm{M}_{n o}\right.$ response $\left.=4.66, \mathrm{M}_{\text {ingratiation }}=4.19, t(81)=1.83, p>.05\right)$ did not hold when the SMI was present, despite the values-driven motives. Consistent with Study 1, the presence of the SMI led to the ingratiation response strategy performing in a way that is comparable to a no response strategy (see Appendix E).

To test H5-H6, which are the focus of Study 2, we estimated a moderated mediation model using 10,000 resamples and estimated confidence intervals (Model 7; Hayes, 2018). The results are presented in Table 4. Consistent with our hypotheses, the moderation of crisis response source motives was largely supported by the data given the index of moderated mediation ( $p=.06$; Hayes, 2018). To explain the nature of the moderation and to test if the results hold when measuring perceived motives, we ran a moderated mediation model using a measure of values-driven motives (Vlacos et al., 2009). The direct effect from ingratiation to manipulative intentions was significant and negative when values-driven motives were high (1SD above the mean; -.68, CI $=-1.22$ to -.14 ), but not significant when values-driven motives were medium or average $(.04 ; \mathrm{CI}=-.34$ to .41$)$. Intriguingly, the direct effect from 
ingratiation to manipulative intentions was significant but positive when values-driven motives were low (1SD below the mean; $.75, \mathrm{CI}=.24$ to 1.27 ). The indirect effects showed that ingratiation increased competence, honesty and benevolence via reduced manipulative intent inferences only when values-driven motives were high (Competence: .45, $\mathrm{CI}=.15$ to .78 ; Honesty: $.53, \mathrm{CI}=.18$ to .88 ; Benevolence: $.54, \mathrm{CI}=.19$ to .92$)$. The effect was, however, not statistically significant when values-driven motives were medium, and it was significant but reversed when values-driven motives were low.

$<$ insert Table 4>

\section{General discussion}

The two experimental studies find empirical support for our conceptual model. While ingratiation alone seems to be an effective crisis response strategy when compared with no response, its effect changes when a social media influencer supports the brand in its crisis communications. The presence of a SMI raises suspicion toward the corporate brand. This results in manipulative intent inferences and perceptions toward some components of brand trustworthiness being comparable across ingratiation and no response strategies. Both manipulative intent inferences and perceived brand trustworthiness sequentially influence corporate reputation perceptions only when there is no SMI (vs SMI is present). Consistent with persuasion knowledge literature (Campbell, 1995; Friestad \& Wright, 1994; Isaac \& Grayson, 2017), the influencer's presence shows a low credibility tactic, which is persuasive in nature and thus enhances persuasion knowledge access, which ultimately leads consumers to resist the crisis response message. This is manifested in inferences of manipulative intent and perceptions of honesty, which are at comparable levels across ingratiation and no response strategies if the SMI is present.

Interestingly, we find that the limitation ensuing from employing SMIs in crisis communications can be offset. Results from our second experimental study show that the 
process of disclosing values-driven motives behind the crisis response source (i.e. the SMI and the brand) counterbalance the negative effect of SMIs' presence. When altruistic, valuesdriven motives behind the SMI-brand partnership and their crisis communications become salient, ingratiation response diminishes manipulative intent inferences while increasing perceptions of brand trustworthiness, which is conducive to positive ratings of corporate reputation. Consistent with persuasion knowledge literature and attribution theory (DeCarlo, 2005; Weiner, 1985), information that counters negative expectations and cognitive schema triggered by the influencer's presence leads to positive attributions benefitting the brand.

\subsection{Theoretical contributions}

Our study makes notable contributions to knowledge in the areas of corporate crisis communications, influencer marketing, and corporate reputation management. Our first contribution lies in advancing knowledge on the role of SMIs in corporate crisis communications. Our study is the first to empirically investigate how the presence of SMIs in crisis communications impacts consumers' perceptions of corporate brands undergoing a crisis. Extant research suggests that, under normal conditions, the employment of SMIs is beneficial to brands (e.g., Colliander \& Dahlén, 2011; Djafarova \& Rushworth, 2017). However, prior research assumes that consumers passively accept information from SMIs at face value (e.g., Dutta \& Pullig, 2011). In doing so, prior literature overlooks the possibility that consumers might rather resist messages from persuasive sources such as brand representatives (i.e. SMIs), especially in the context of crises. We argue that, in the context of crises, messages from SMIs are interpreted as persuasive attempts of the brand. Such messages activate suspicion and cognitive schema that the SMI and the brand are partnering in crisis communications in order to persuade consumers into believing that the crisis is not as severe as it appears, while also protecting themselves from further consumer backlash. 
Given the prevalent consumer cynicism toward corporate brands and their representatives (Kirmani \& Zhu, 2007), crisis responses provided by the brand in partnership with SMIs generate inferences of manipulative intent. This is evidenced by our findings showing that manipulative intent inferences are lower and perceived trustworthiness is higher when ingratiation response is rendered by the brand alone. However, the advantage of an ingratiation response strategy does not hold when the brand seeks support from an influencer. Given their prominent status as brand representatives, SMIs seem to heighten consumer suspicion of the brand's manipulative intent in crisis management efforts (e.g., Campbell \& Kirmani, 2000). At a more general level, the evidence from our studies highlight drawbacks associated with the employment of SMIs in crisis communications. While related to the corporate crisis context, our findings are useful for influencer marketing efforts more broadly and suggest that influencer marketing might be less effective than suggested in prior research. Evidence from our findings will stimulate research on influencer marketing, and more widely on brand endorsements, that could account for consumers' skepticism.

Further, our study contributes to advancing understanding on remedies to the drawbacks associated with the presence of SMIs in crisis management. Specifically, we show how the communication of values-driven motives on the part of the brand and of the endorsing influencer lowers consumers' skepticism. Drawing upon attribution theory (Heider, 1958; Weiner, 1985) and evidence from persuasion knowledge literature (e.g., DeCarlo, 2005; Isaac \& Grayson, 2017), we show that customer-oriented and suspicion-oriented attributions are key in explaining responses to persuasive messages. Crises invariably lead to suspicionoriented attributions and negative cognitive schema, which are further strengthened when a persuasive source such as an influencer is present. We demonstrate how information that counters existing negative expectations and cognitive schema can, by contrast, trigger customer-oriented attributions, which result in marginally more positive perceptions of 
consumers. Thus, our second contribution lies in providing theoretical explanation of when and how SMIs can be employed in crisis communications. We expand upon existing research by clarifying how SMIs influence brand-consumer relationships following crises. Social media influencers command mass followings (e.g., Zoella's 11m YouTube subscribers), and given their unabated popularity, our findings lay foundation for further theoretical advancements on the strategies that can help brands to leverage on their collaboration with SMIs in crisis communications.

Our third contribution concerns advancements in knowledge related to corporate crisis responses and their effects on consumers. We examine a largely overlooked crisis response strategy, namely ingratiation, and particularly its interaction with influencers' presence. By drawing upon persuasion knowledge theory, we find that the interplay of crisis response message (i.e. ingratiation) and crisis response source (i.e. SMI presence) rests on inferences of manipulative intent and perceptions of brand trustworthiness, both influential in shaping corporate reputation. Manipulative intent and brand trustworthiness are identified here as key mechanisms explaining the post-crisis perceptions of corporate reputation. Our research thus represents the initial advancement in showing that the above two appraisals of crisis response are influential in promoting the ingratiation-corporate reputation link.

\subsection{Managerial implications}

The prevalence of social media channels and the continued popularity of influencer marketing suggest that such a potent force for a brand's communication strategy should not be ignored. Our findings, however, show risks associated with the use of social media influencers (SMIs) in crisis communications. We recommend brands to follow a circumspect approach when considering the presence of SMIs in crisis communications.

First, compared to no response, an ingratiation response by corporate brands can lower consumers' perception of manipulative intent while enhancing perceived brand 
trustworthiness, and both aspects are crucial for sustained good corporate reputation. Using cues to remind stakeholders of the corporate brand's past good work, therefore, represents a viable option for upholding good reputation in the marketplace following crises. However, managers should be warned that if a SMI is involved in supporting a bolstering response to crisis, the brand risks eliciting persuasion knowledge access and suspicion that the brand's intent is to convey diminished severity of the crisis. The desirable outcomes provided by an ingratiation response, such as lowered manipulative intent and heightened trustworthiness, could be undermined by the presence of an influencer. As evidenced by our findings, the presence of an influencer discounts the effect of ingratiation response in enhancing perceptions of brand trustworthiness and in lowering inferences of manipulative intent. In other words, ingratiation somewhat 'loses' its advantage over a no response strategy when the SMI is present. Given that both perceived trustworthiness and manipulative intent inferences impact post-crisis corporate reputation, managers are advised to avoid employing SMIs in post-crisis communications. The brand's attempt at ingratiation on its own appears to result in more favorable outcomes.

Second, our findings offer recommendations for crisis situations whereby the influencer is already part of a company's marketing efforts, and therefore, their involvement in crisis communications is somewhat predictable. For example, in a well-known case, a popular SMI issued a statement on Instagram aimed at genuinely warning her followers of the potentially harmful side effects of a previously endorsed drug (Ad Age, 2015). In other instances, SMIs might intervene in crisis communications to fulfil their obligations toward the partnering brand (e.g., contracted agreement), and/or in their effort to pre-empt any backlash from the brand crisis. Our research suggests that, in circumstances where SMIs inevitably contribute to the brand's crisis communications, consumers are willing to accept efforts which are believed to emanate from values-driven motives of the brand and of the partnering influencer. 
In such instances, the disclosure of values-driven motives behind the brand-influencer partnership results in ingratiation leading to enhanced competence, honesty, and benevolence via diminished manipulative intent, and in turn, positive perceptions of corporate reputation. Marketing and communications managers are, therefore, advised to ensure that valuesdriven motives are conveyed alongside any ingratiation response, when the SMI is present. In this regard, the SMI is advised to communicate their altruistic concerns to followers and publicly disclose that no additional monetary incentives were received for the message posted. The above will help the brand to optimize its partnership with a SMI. On the other hand, we find that ingratiation can be detrimental if consumers attribute low values-driven motives to the brand-influencer partnership, as manipulative intent perceptions would be strengthened.

\section{Limitations and areas for future research}

The limitations of our study provide fruitful areas for future research. We focus on manipulative intent inferences and perceived brand trustworthiness as sequential mediators in explaining the ingratiation-corporate reputation link. This is consistent with research showing that resistance to persuasive attempts of the brand and their representatives affects perceived trustworthiness of the brand (Guo \& Main, 2012), which in turn impacts brand reputation (Walsh et al., 2009). Future research could examine whether such mediators have the same effect when alternative, yet equally important aspects of corporate brand management, such as corporate image, are considered. Furthermore, in Study 2, we examine the motives behind the brand-influencer partnership in explaining consumers' inferences of manipulative intent and perceptions of brand trustworthiness. Consumers' individual traits capturing, for instance, resistance to the persuasive attempts of the brand, such as self-control depletion (Burkley, 2008) or trait-based skepticism (Obermiller \& Spangenberg, 1998), might 
also contribute to explaining motive attributions and consequent manipulative intent inferences, thus could be examined in future research.

In addition, research in organizational settings suggests that ingratiation can be focused on enhancing oneself or enhancing others, with the latter often being more effective at fostering positive perceptions on the part of the target of ingratiation (Koopman et al., 2015). The focus in our study was on self-enhancing ingratiation, whereby the brand bolsters its past good actions. We also examine other-enhancing ingratiation to some extent, by introducing information about the altruistic, values-driven motives of the brand and of the influencer (i.e. how their actions indirectly benefit consumers) in Study 2. By doing so, we show that high values-driven motives are conducive to lower inferences of manipulative intent and greater perceptions of brand trustworthiness. Future research could consider the above dichotomy of self- and other-enhancing ingratiation more explicitly, to establish whether and how otherenhancing ingratiation lowers suspicion and results in more positive perceptions of consumers when compared with self-enhancing ingratiation.

From a methodological perspective, we conducted two scenario-based experiments examining one type of crisis related to a potentially harmful ingredient of a beauty product. While the choice of the beauty industry, crisis and methodology are relevant to existing debates on crisis communications and influencer marketing, our findings could be tested for generalizability to other industries or crisis contexts. Arguably, the severity of the crisis investigated could have partially contributed to heightened suspicion about the brand and crisis management efforts. Findings might change in the context of less severe crises, whereby negativity inherent to the crisis event might be lower. Future research could extend our findings to other crisis types and/or industries, while also adopting alternative methodologies that offer high ecological validity. For instance, longitudinal research might help in detecting consumers' temporal processing of the crisis response, as well as any time- 
related change in consumer perceptions of corporate reputation. Future studies might also

consider SMIs and/or industries that are more relevant to male participants in order to

establish the generalizability of our findings.

\section{References}

Ad Age. Kim Kardashian posts '\#CorrectiveAd,' drug side effects after FDA warning. (2015). https://adage.com/article/digital/kim-kardashian-posts-drug-side-effects-fdawarning/300147/ Accessed 21 July 2019.

Adler, P. S., \& Kwon, S.W. (2002). Social capital: Prospects for a new concept. Academy of Management Review, 27(1), 17-40. https://doi.org/10.5465/amr.2002.5922314.

Antonetti, P., Crisafulli, B., \& Maklan, S. (2018). Too good to be true? Boundary conditions to the use of downward social comparisons in service recovery. Journal of Service Research, 21(4), 438-455. https://doi.org/10.1177/1094670518793534.

Bagozzi, R. P., \& Yi, Y. (1989). On the use of structural equation models in experimental designs. Journal of Marketing Research, 26(3), 271-284. https://doi.org/10.1177/002224378902600302.

Bellezza, S., Paharia, N., \& Keinan, A. (2017). Conspicuous consumption of time: When busyness and lack of leisure time become a status symbol. Journal of Consumer Research, 44(1), 118-138. https://doi.org/10.1093/jcr/ucw076.

Bollen, K., \& Lennox, R. (1991). Conventional wisdom on measurement: A structural equation perspective. Psychological Bulletin, 110(2), 305-314. http://dx.doi.org/10.1037/0033-2909.110.2.305.

Brown, N. A., \& Billings, A. C. (2013). Sports fans as crisis communicators on social media websites. Public Relations Review, 39(1), 74-81. https://doi.org/10.1016/j.pubrev.2012.09.012.

Burkley, E. (2008). The role of self-control in resistance to persuasion. Personality and Social Psychology Bulletin, 34(3), 419-431. https://doi.org/10.1177/0146167207310458.

Campbell, M. C. (1995). When attention-getting advertising tactics elicit consumer inferences of manipulative intent: The importance of balancing benefits and investments. Journal of Consumer Psychology, 4(3), 225-254.

https://doi.org/10.1207/s15327663jcp0403_02.

Campbell, M. C., \& Kirmani, A. (2000). Consumers' use of persuasion knowledge: The effects of accessibility and cognitive capacity on perceptions of an influence agent. Journal of Consumer Research, 27(1), 69-83. https://doi.org/10.1086/314309.

Carrillat, F. A., d'Astous, A., \& Lazure, J. (2013). For better, for worse? What to do when celebrity endorsement goes bad. Journal of Advertising Research, 53(1), 15-30. https://doi.org/10.2501/JAR-53-1-015-030.

Claeys, A. S., \& Cauberghe, V. (2014). What makes crisis response strategies work? The impact of crisis involvement and message framing. Journal of Business Research, 67(2), 182-189. https://doi.org/10.1016/j.jbusres.2012.10.005.

Claeys, A. S., Cauberghe, V., \& Vyncke, P. (2010). Restoring reputations in times of crisis: An experimental study of the situational crisis communication theory and the moderating effects of locus of control. Public Relations Review, 36(3), 256-262. https://doi.org/10.1016/j.pubrev.2010.05.004.

Cleeren, K., Van Heerde, H. J., \& Dekimpe, M. G. (2013). Rising from the ashes: How brands and categories can overcome product-harm crises. Journal of Marketing, 77(2), 5877. https://doi.org/10.1509/jm.10.0414. 
Cocker, H. L., \& Cronin, J. (2017). Charismatic authority and the YouTuber: Unpacking the new cults of personality. Marketing Theory, 17(4), 455-472. https://doi.org/10.1177/1470593117692022.

Colliander, J., \& Dahlén, M. (2011). Following the fashionable friend: the power of social media: weighing publicity effectiveness of blogs versus online magazines. Journal of Advertising Research, 51(1), 313-320. https://doi.org/10.2501/JAR-51-1-313-320.

Connelly, B. L., Certo, S. T., Ireland, R. D., \& Reutzel, C. R. (2011). Signaling theory: A review and assessment. Journal of Management, 37(1), 39-67. https://doi.org/10.1177/0149206310388419.

Coombs, W. T. (1995). Choosing the right words: The development of guidelines for the selection of the "appropriate" crisis response strategies. Management Communication Quarterly, 8(4), 447-476. https://doi.org/10.1177/0893318995008004003.

Coombs, W. T. (1998). An analytic framework for crisis situations: Better responses from a better understanding of the situation, Journal of Public Relations Research, 10(3), 177 191. https://doi.org/10.1207/s1532754xjprr1003_02.

Coombs, W. T. (2007). Protecting organization reputations during a crisis: The development and application of situational crisis communication theory. Corporate Reputation Review, 10(3), 163-177. https://doi.org/10.1057/palgrave.crr.1550049.

Coombs, W. T. (2010). Parameters for crisis communication. In W.T. Coombs \& S. J. Holladay (Eds.), The handbook of crisis communication (pp. 17-53). Chichester: Blackwell Publishing Ltd. https://doi.org/10.1002/9781444314885.ch1.

Crijns, H., Cauberghe, V., Hudders, L., \& Claeys, A. S. (2017). How to deal with online consumer comments during a crisis? The impact of personalized organizational responses on organizational reputation. Computers in Human Behavior, 75, 619-631. https://doi.org/10.1016/j.chb.2017.05.046.

Dardis, F., \& Haigh, M. M. (2009). Prescribing versus describing: Testing image restoration strategies in a crisis situation. Corporate Communications: An International Journal, 14(1), 101-118. https://doi.org/10.1108/13563280910931108.

DeCarlo, T. E. (2005). The effects of sales message and suspicion of ulterior motives on salesperson evaluation. Journal of Consumer Psychology, 15(3), 238-249. https://doi.org/10.1207/s15327663jcp1503_9.

Djafarova, E., \& Rushworth, C. (2017). Exploring the credibility of online celebrities' Instagram profiles in influencing the purchase decisions of young female users. Computers in Human Behavior, 68, 1-7. https://doi.org/10.1016/j.chb.2016.11.009.

Djafarova, E., \& Trofimenko, O. (2018). 'Instafamous'-credibility and self-presentation of micro-celebrities on social media. Information, Communication \& Society, 22(10) 14321446. https://doi.org/10.1080/1369118X.2018.1438491.

Doney, P. M., \& Cannon, J. P. (1997). An examination of the nature of trust in buyer-seller relationships. Journal of Marketing, 61(2), 35-51. https://doi.org/10.1177/002224299706100203.

Dutta, S., \& Pullig, C. (2011). Effectiveness of corporate responses to brand crises: The role of crisis type and response strategies. Journal of Business Research, 64(12), 1281-1287. https://doi.org/10.1016/j.jbusres.2011.01.013.

Eagly, A. H., Wood, W., \& Chaiken, S. (1978). Causal inferences about communicators and their effect on opinion change. Journal of Personality and Social Psychology, 36(4), 424435. http://dx.doi.org/10.1037/0022-3514.36.4.424.

Fein, S., \& Hilton, J. L. (1994). Judging others in the shadow of suspicion. Motivation and Emotion, 18(2), 167-198. https://doi.org/10.1007/BF02249398. 
Fein, S., Hilton, J. L., \& Miller, D. T. (1990). Suspicion of ulterior motivation and the correspondence bias. Journal of Personality and Social Psychology, 58(5), 753-764. $\mathrm{http} / / / \mathrm{dx}$.doi.org/10.1037/0022-3514.58.5.753.

Ferchaud, A., Grzeslo, J., Orme, S., \& LaGroue, J. (2018). Parasocial attributes and YouTube personalities: Exploring content trends across the most subscribed YouTube channels. Computers in Human Behavior, 80, 88-96. https://doi.org/10.1016/j.chb.2017.10.041.

Ferrin, D. L., Kim, P. H., Cooper, C. D., \& Dirks, K. T. (2007). Silence speaks volumes: The effectiveness of reticence in comparison to apology and deny for responding to integrity and competence-based trust violations. Journal of Applied Psychology, 92(4), 893-908. http://dx.doi.org/10.1037/0021-9010.92.4.893.

Firstpost. Is the McDonald's 'Masala Dosa Brioche' burger as terrifying as we expected it to be? (2017). https://www.firstpost.com/blogs/life-blogs/is-the-mcdonalds-masala-dosabrioche-burger-as-terrifying-as-we-expected-it-to-be-3206076.html/ Accessed 27 January 2019.

Fornell, C., \& Larcker, D. F. (1981). Structural equation models with unobservable variables and measurement error: Algebra and statistics. Journal of Marketing Research, 18(3), 382388. https://doi.org/10.1177/002224378101800313.

Friestad, M., \& Wright, P. (1994). The persuasion knowledge model: How people cope with persuasion attempts. Journal of Consumer Research, 21(1), 1-31. https://doi.org/10.1086/209380.

Gordon, R. A. (1996). Impact of ingratiation on judgments and evaluations: A meta-analytic investigation. Journal of Personality and Social Psychology, 71(1), 54-70. http://dx.doi.org/10.1037/0022-3514.71.1.54.

Guo, W., \& Main, K. J. (2012). The vulnerability of defensiveness: The impact of persuasion attempts and processing motivations on trust. Marketing Letters, 23(4), 959-971. https://doi.org/10.1007/s11002-012-9197-y.

Haigh, M. M., \& Brubaker, P. (2010). Examining how image restoration strategy impacts perceptions of corporate social responsibility, organization-public relationships, and source credibility. Corporate Communications: An International Journal, 15(4), 453-468. https://doi.org/10.1108/13563281011085538.

Hair, J. R., Hult, J. F., Ringle, G. T. M., \& Sarstedt, M. (2016). A primer on partial least squares structural equation modelling (PLS-SEM). Thousand Oaks: Sage Publications.

Hayes, A. F. (2018). Introduction to mediation, moderation, and conditional process analysis: A regression-based approach. (2nd ed.). New York: The Guilford Press.

Heider, F. (1958). The psychology of interpersonal relations. New York: Wiley.

Higgins, C. A., Judge, T. A., \& Ferris, G. R. (2003). Influence tactics and work outcomes: A meta-analysis. Journal of Organizational Behavior, 24(1), 89-106. https://doi.org/10.1002/job.181.

Hsu, L., \& Lawrence, B. (2016). The role of social media and brand equity during a product recall crisis: A shareholder value perspective. International Journal of Research in Marketing, 33(1), 59-77. https://doi.org/10.1016/j.ijresmar.2015.04.004.

Hsu, C. L., Lin, C. C J., \& Chiang, H. S. (2013). The effects of blogger recommendations on customers' online shopping intentions. Internet Research, 23(1), 69-88. https://doi.org/10.1108/10662241311295782.

Hwang, K., \& Zhang, Q. (2018). Influence of para-social relationship between digital celebrities and their followers on followers' purchase and electronic word-of-mouth intentions, and persuasion knowledge. Computers in Human Behavior, 87, 155-173. https://doi.org/10.1016/j.chb.2018.05.029. 
Isaac, M. S., \& Grayson, K. (2017). Beyond skepticism: Can accessing persuasion knowledge bolster credibility? Journal of Consumer Research, 43(6), 895-912. https://doi.org/10.1093/jcr/ucw063.

Jin, Y. (2014). Examining publics' crisis responses according to different shades of anger and sympathy. Journal of Public Relations Research, 26(1), 79-101. https://doi.org/10.1080/1062726X.2013.848143.

Jin, S. A. A., \& Phua, J. (2014). Following celebrities' tweets about brands: The impact of twitter-based electronic word-of-mouth on consumers' source credibility perception, buying intention, and social identification with celebrities. Journal of Advertising, 43(2), 181-195. https://doi.org/10.1080/00913367.2013.827606.

Kapitan, S., \& Silvera, D. H. (2016). From digital media influencers to celebrity endorsers: Attributions drive endorser effectiveness. Marketing Letters, 27(3), 553-567. https://doi.org/10.1007/s11002-015-9363-0.

Kim, P. H., Ferrin, D. L., Cooper, C. D., \& Dirks, K. T. (2004). Removing the shadow of suspicion: The effects of apology versus denial for repairing competence-versus integritybased trust violations. Journal of Applied Psychology, 89(1), 104-118. http://dx.doi.org/10.1037/0021-9010.89.1.104.

Kirmani, A., \& Zhu, R. (2007). Vigilant against manipulation: The effect of regulatory focus on the use of persuasion knowledge. Journal of Marketing Research, 44(4), 688-701. https://doi.org/10.1509/jmkr.44.4.688.

Klein, J., \& Dawar, N. (2004). Corporate social responsibility and consumers' attributions and brand evaluations in a product-harm crisis. International Journal of Research in Marketing, 21(3), 203-217. https://doi.org/10.1016/j.ijresmar.2003.12.003.

Koopman, J., Matta, F. K. L., Scott, B. A., \& Conlon, D. E. (2015). Ingratiation and popularity as antecedents of justice: A social exchange and social capital perspective. Organizational Behavior and Human Decision Processes, 131, 132-148. https://doi.org/10.1016/j.obhdp.2015.09.001.

Lee, J. E., \& Watkins, B. (2016). YouTube vloggers' influence on consumer luxury brand perceptions and intentions. Journal of Business Research, 69(12), 5753-5760. https://doi.org/10.1016/j.jbusres.2016.04.171.

Lemmer, G., \& Gollwitzer, M. (2017). The "true" indirect effect won't (always) stand up: When and why reverse mediation testing fails. Journal of Experimental Social Psychology, 69, 144-149. https://doi.org/10.1016/j.jesp.2016.05.002.

Liljander, V., Gummerus, J., \& Söderlund, M. (2015). Young consumers' responses to suspected covert and overt blog marketing. Internet Research, 25(4), 610-632. https://doi.org/10.1108/IntR-02-2014-0041.

Liu, B. F., Austin, L., \& Jin, Y. (2011). How publics respond to crisis communication strategies: The interplay of information form and source. Public Relations Review, 37(4), 345-353. https://doi.org/10.1016/j.pubrev.2011.08.004.

Liu, Y., \& Shankar, V. (2015). The dynamic impact of product-harm crises on brand preference and advertising effectiveness: An empirical analysis of the automobile industry. Management Science, 61(10), 2514-2535. https://doi.org/10.1287/mnsc.2014.2095.

Lu, L. C., Chang, W. P., \& Chang, H. H. (2014). Consumer attitudes toward blogger's sponsored recommendations and purchase intention: The effect of sponsorship type, product type, and brand awareness. Computers in Human Behavior, 34, 258-266. https://doi.org/10.1016/j.chb.2014.02.007.

Mardon, R., Molesworth, M., \& Grigore, G. (2018). YouTube Beauty Gurus and the emotional labour of tribal entrepreneurship. Journal of Business Research, 92, 443-454. https://doi.org/10.1016/j.jbusres.2018.04.017. 
Moore, D. J., Mowen, J. C., \& Reardon, R. (1994). Multiple sources in advertising appeals: When product endorsers are paid by the advertising sponsor. Journal of the Academy of Marketing Science, 22(3), 234-243. https://doi.org/10.1177/0092070394223004.

Obermiller, C., \& Spangenberg, E. R. (1998). Development of a scale to measure consumer skepticism toward advertising. Journal of Consumer Psychology, 7(2), 159-186. https://doi.org/10.1207/s15327663jcp0702_03.

Park, H. (2017). Exploring effective crisis response strategies. Public Relations Review, 43(1), 190-192. https://doi.org/10.1016/j.pubrev.2016.12.001.

Park, J., Lee, H., \& Kim, C. (2014). Corporate social responsibilities, consumer trust and corporate reputation: South Korean consumers' perspectives. Journal of Business Research, 67(3), 295-302. https://doi.org/10.1016/j.jbusres.2013.05.016.

Rao, A. R., Qu, L., \& Ruekert, R. W. (1999). Signaling unobservable product quality through a brand ally. Journal of Marketing Research, 36(2), 258-268. https://doi.org/10.1177/002224379903600209.

Schomer, A. (2019). Influencer Marketing: State of the social media influencer market in 2020 https://www.businessinsider.com/influencer-marketing-report? $\mathrm{r}=\mathrm{US} \& \mathrm{IR}=\mathrm{T}$ Accessed $29^{\text {th }}$ Feb 2020.

Schriesheim, C. A., Castro, S. L., \& Yammarino, F. J. (2000). Investigating contingencies: An examination of the impact of span of supervision and upward controllingness on leader-member exchange using traditional and multivariate within-and between-entities analysis. Journal of Applied Psychology, 85(5), 659-677. http://dx.doi.org/10.1037/00219010.85.5.659.

Simmons, C. J., \& Becker-Olsen, K. L. (2006). Achieving marketing objectives through social sponsorships. Journal of Marketing, 70(4), 154-169. https://doi.org/10.1509/jmkg.70.4.154.

Singh, J., Crisafulli, B., \& Quamina, L.T. (2019a). How intensity of cause-related marketing guilt appeals influences consumers: The roles of company motive and consumer identification with the brand. Journal of Advertising Research. https://dx.doi.org/10.2501/JAR-2018-049.

Singh, J., Crisafulli, B., \& Quamina, L.T. (2019b). 'Corporate image at stake': The impact of crises and response strategies on consumer perceptions of corporate brand alliances. Journal of Business Research. https://doi.org/10.1016/j.jbusres.2019.01.014.

Sparkman Jr, R. M. (1982). The discounting principle in the perception of advertising. Advances in Consumer Research, 9(1), 277-280.

Spence, M. (1973). Job market signaling. The Quarterly Journal of Economics, 87(3), 355374. https://doi.org/10.2307/1882010.

Statista. Consumer attitude towards influencer marketing in the United Kingdom (UK) in 2018 (2018). https://www.statista.com/statistics/822171/influencer-marketing-consumerattitude-in-the-uk/ Accessed 13 June 2018.

Sujan, M., Bettman, J. R., \& Sujan, H. (1986). Effects of consumer expectations on information processing in selling encounters. Journal of Marketing Research, 23(4), 346353. https://doi.org/10.1177/002224378602300404.

Szykman, L. R., Bloom, P. N., \& Blazing, J. (2004). Does corporate sponsorship of a socially-oriented message make a difference? An investigation of the effects of sponsorship identity on responses to an anti-drinking and driving message. Journal of Consumer Psychology, 14(1-2) 13-20. https://doi.org/10.1207/s15327663jcp1401\&2_3.

Thomas, V. L., \& Fowler, K. (2016). Examining the impact of brand transgressions on consumers' perceptions of celebrity endorsers. Journal of Advertising, 45(4), 377-390. https://doi.org/10.1080/00913367.2016.1172385. 
Uzunoğlu, E., \& Kip, S. M. (2014). Brand communication through digital influencers: Leveraging blogger engagement. International Journal of Information Management, 34(5), 592-602. https://doi.org/10.1016/j.ijinfomgt.2014.04.007.

Vlacos, P. A., Tsamakos, A., Vrechopoulos, A. P., \& Avramidis, P. K. (2009). Corporate social responsibility: Attributions, loyalty, and the mediating role of trust. Journal of the Academy of Marketing Science, 37(2), 170-180. https://doi.org/10.1007/s11747-008-0117$\mathrm{X}$.

Vonk, R. (2002). Self-serving interpretations of flattery: Why ingratiation works. Journal of Personality and Social Psychology, 82(4), 515-526. http://dx.doi.org/10.1037/00223514.82.4.515.

Walsh, G., Mitchell, V. W., Jackson, P. R., \& Beatty, S. E. (2009). Examining the antecedents and consequences of corporate reputation: A customer perspective. British Journal of Management, 20(2), 187-203. https://doi.org/10.1111/j.14678551.2007.00557.x.

WARC. What we know about influencer marketing. (2019). https://www.warc.com/content/paywall/article/bestprac/what we know about influencer marketing/111564 Accessed 30 July 2019.

Wayne, S. J., \& Ferris, G. R. (1990). Influence tactics, affect, and exchange quality in supervisor-subordinate interactions: A laboratory experiment and field study. Journal of Applied Psychology, 75(5), 487-499. http://dx.doi.org/10.1037/0021-9010.75.5.487.

Wayne, S. J., \& Liden, R. C. (1995). Effects of impression management on performance ratings: A longitudinal study. Academy of Management Journal, 38(1), 232-260. https://doi.org/10.5465/256734.

Weiner, B. (1985). An attributional theory of achievement motivation and emotion. Psychological Review, 92(4), 548-573. http://dx.doi.org/10.1037/0033-295X.92.4.548.

Westphal, J. D., \& Stern, I. (2007). Flattery will get you everywhere (especially if you are a male Caucasian): How ingratiation, boardroom behavior, and demographic minority status affect additional board appointments at US companies. Academy of Management Journal, 50(2), 267-288. https://doi.org/10.5465/amj.2007.24634434.

World Federation of Advertisers. Brands to invest more on influencers. (2018). https://www.wfanet.org/news-centre/multinational-brands-focus-on-influencertransparency/ Accessed 30 July 2018.

Xie, Y., \& Peng, S. (2009). How to repair customer trust after negative publicity: The roles of competence, integrity, benevolence, and forgiveness. Psychology \& Marketing, 26(7), 572-589. https://doi.org/10.1002/mar.20289.

Yoon, Y., Gürhan-Canli, Z., \& Schwarz, N. (2006). The effect of corporate social responsibility (CSR) activities on companies with bad reputations. Journal of Consumer Psychology, 16(4), 377-390. https://doi.org/10.1207/s15327663jcp1604_9. 
Figure 1: Conceptual model

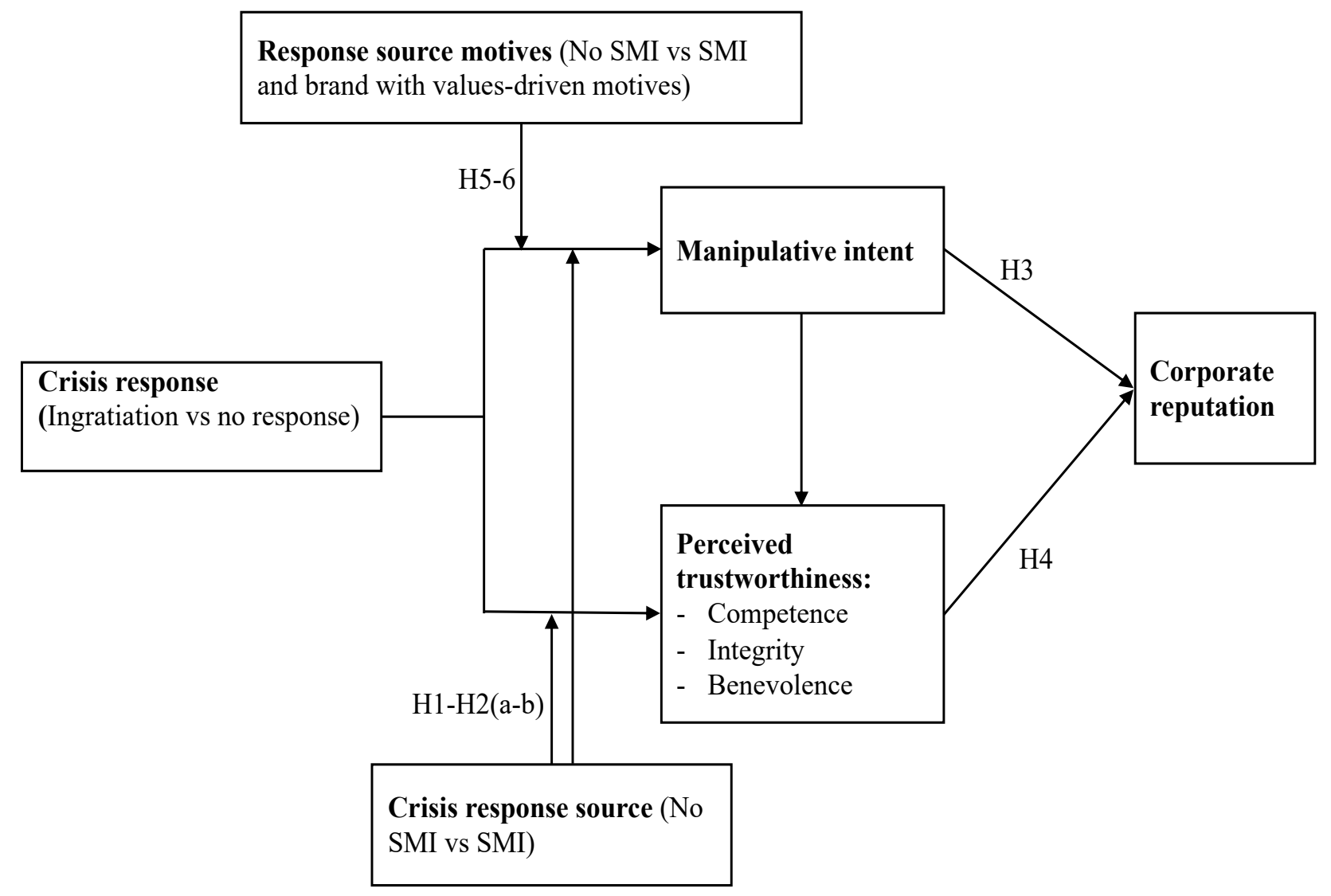


Table 1: Summary of the key literature on social media influencers

\begin{tabular}{|c|c|c|c|c|c|}
\hline Study & Focus & Method & $\begin{array}{l}\text { Construct(s) } \\
\text { examined }\end{array}$ & Dependent Variable(s) & Key Finding(s) \\
\hline $\begin{array}{l}\text { Colliander \& } \\
\text { Dahlén } \\
(2011)\end{array}$ & $\begin{array}{l}\text { Brand publicity in blogs vs. } \\
\text { online magazines }\end{array}$ & Survey & $\begin{array}{l}\text { - Blogger credibility } \\
\text { - Blogger-brand } \\
\text { relationship }\end{array}$ & $\begin{array}{l}\text { - Para Social } \\
\text { Interaction (PSI) } \\
\text { - Brand attitudes } \\
\text { - Purchase intentions }\end{array}$ & $\begin{array}{l}\text { Blogs are more credible and generate higher perceptions of PSI, } \\
\text { brand attitudes and purchase intentions than online magazines. } \\
\text { Blogger credibility and blogger-brand relationship have a } \\
\text { greater positive effect on publicity effectiveness (brand attitude } \\
\text { and purchase intention) on blogs than in online magazines. }\end{array}$ \\
\hline $\begin{array}{l}\text { Hsu et al. } \\
(2013)\end{array}$ & $\begin{array}{l}\text { To examine the effect of } \\
\text { blogger recommendations } \\
\text { on } \\
\text { online purchase decisions }\end{array}$ & Survey & $\begin{array}{l}\text { - Perceived } \\
\text { usefulness of } \\
\text { recommendations } \\
\text { - Trust } \\
\text { - Blogger reputation }\end{array}$ & $\begin{array}{l}\text { - Attitude toward } \\
\text { online shopping } \\
\text { - Intentions to shop } \\
\text { online }\end{array}$ & $\begin{array}{l}\text { Perceived usefulness and trust of bloggers' recommendation } \\
\text { positively affects attitude and purchase intention. Blogger } \\
\text { reputation moderates the effect; for high (vs. low) reputation } \\
\text { bloggers, trust (vs. perceived usefulness of recommendation) is } \\
\text { most important. }\end{array}$ \\
\hline $\begin{array}{l}\text { Lu et al. } \\
(2014)\end{array}$ & $\begin{array}{l}\text { To examine attitudes } \\
\text { toward sponsored } \\
\text { recommendation blog posts } \\
\text { and purchase intentions }\end{array}$ & Experiment & $\begin{array}{l}\text { - Sponsorship type } \\
\text { - Product type } \\
\text { - Brand awareness }\end{array}$ & $\begin{array}{l}\text { - Attitude toward the } \\
\text { recommendation } \\
\text { - Purchase intentions }\end{array}$ & $\begin{array}{l}\text { Consumers show positive attitudes toward recommendation } \\
\text { posts and purchase intentions when recommended products are } \\
\text { search goods or have high brand awareness. The sponsorship } \\
\text { type (i.e. cash vs. discounts) of bloggers has no effect on } \\
\text { perceptions. }\end{array}$ \\
\hline $\begin{array}{l}\text { Lee \& } \\
\text { Watkins } \\
(2016)\end{array}$ & $\begin{array}{l}\text { To assess the influence of } \\
\text { vlogs on consumer luxury } \\
\text { brand perceptions and } \\
\text { intentions }\end{array}$ & $\begin{array}{l}\text { Survey } \\
\text { (Study1) } \\
\text { Experiment } \\
\text { (Study 2\&3) }\end{array}$ & $\begin{array}{l}\text { - Social } \\
\text { attractiveness } \\
\text { - Physical } \\
\text { attractiveness } \\
\text { - Attitude homophily }\end{array}$ & $\begin{array}{l}\text { - Para Social } \\
\text { Interaction (PSI) } \\
\text { - Luxury brand } \\
\text { perceptions } \\
\text { - Purchase intentions }\end{array}$ & $\begin{array}{l}\text { Luxury brand perceptions are higher among consumers exposed } \\
\text { to messages from vloggers, when a PSI is in place. PSI is } \\
\text { enhanced by social attractiveness, attitude homophily and } \\
\text { physical attractiveness. }\end{array}$ \\
\hline $\begin{array}{l}\text { Djafarova \& } \\
\text { Rushworth } \\
(2017)\end{array}$ & $\begin{array}{l}\text { To understand the role of } \\
\text { social media influencers in } \\
\text { shaping female consumers' } \\
\text { purchase decisions }\end{array}$ & Interviews & -- & -- & $\begin{array}{l}\text { Social media influencers are perceived as credible and easy to } \\
\text { relate to, more than celebrities. Female consumers tend to follow } \\
\text { social media influencers using attractive images, and providing } \\
\text { positive product reviews. }\end{array}$ \\
\hline $\begin{array}{l}\text { Cocker \& } \\
\text { Cronin } \\
(2017)\end{array}$ & $\begin{array}{l}\text { To understand the nature of } \\
\text { appeal gained by } \\
\text { YouTubers }\end{array}$ & Netnography & -- & -- & $\begin{array}{l}\text { YouTubers' charisma and personality enhance their authority, } \\
\text { which in turn influences perceived proximity and interaction } \\
\text { with consumers. }\end{array}$ \\
\hline
\end{tabular}




\begin{tabular}{|c|c|c|c|c|c|}
\hline $\begin{array}{l}\text { Ferchaud et } \\
\text { al. (2018) }\end{array}$ & $\begin{array}{l}\text { Content trends on popular } \\
\text { YouTube channels }\end{array}$ & $\begin{array}{l}\text { Content } \\
\text { analysis }\end{array}$ & $\begin{array}{l}\text { - Self-disclosure } \\
\text { - Parasocial } \\
\text { attributes } \\
\text { (personality and } \\
\text { behavior) }\end{array}$ & $\begin{array}{l}\text { - Perceived realism } \\
\text { - Authenticity }\end{array}$ & $\begin{array}{l}\text { Self-disclosure (i.e. the YouTuber reveals something about } \\
\text { his/her personal life) is positively related to higher levels of } \\
\text { authenticity and realism. } \\
\text { Female YouTubers are associated with higher levels of realism } \\
\text { compared to Male YouTubers. }\end{array}$ \\
\hline $\begin{array}{l}\text { Djafarova \& } \\
\text { Trofimenko } \\
(2018)\end{array}$ & $\begin{array}{l}\text { Perceived credibility of } \\
\text { social media influencers on } \\
\text { consumer attitude and } \\
\text { behavior }\end{array}$ & $\begin{array}{l}\text { In-depth } \\
\text { interview }\end{array}$ & $\begin{array}{l}\text { - Online source } \\
\text { credibility }\end{array}$ & - & $\begin{array}{l}\text { Social media influencers are not considered as a credible source } \\
\text { of information to influence consumer behavior. } \\
\text { Attractiveness, trustworthiness, competence and online } \\
\text { behavior/self-presentation are key components in achieving } \\
\text { online source credibility. }\end{array}$ \\
\hline $\begin{array}{l}\text { Mardon et al. } \\
(2018)\end{array}$ & $\begin{array}{l}\text { To understand the role of } \\
\text { emotional labour in tribal } \\
\text { entrepreneurship's success }\end{array}$ & Netnography & $\begin{array}{l}\text { - Emotional Labor } \\
\text { - Tribal } \\
\text { entrepreneurship }\end{array}$ & - & $\begin{array}{l}\text { Emotional censorship, self-conscious emotional labor and other } \\
\text { praising enhance the success of YouTubers' tribal } \\
\text { entrepreneurship. }\end{array}$ \\
\hline $\begin{array}{l}\text { Hwang \& } \\
\text { Zhang (2018) }\end{array}$ & $\begin{array}{l}\text { To examine the impact of } \\
\text { follower-influencer } \\
\text { parasocial relationships on } \\
\text { followers' behavior and } \\
\text { persuasion knowledge }\end{array}$ & Survey & $\begin{array}{l}\text { - Empathy } \\
\text { - Loneliness } \\
\text { - Low-self-esteem } \\
\text { - Persuasion } \\
\text { knowledge } \\
\end{array}$ & $\begin{array}{l}\text { - Purchase intention } \\
\text { - Electronic word-of- } \\
\text { mouth (eWOM) }\end{array}$ & $\begin{array}{l}\text { Empathy and low self-esteem positively influence parasocial } \\
\text { relationships, which in turn affect purchase and eWOM } \\
\text { intentions. Parasocial relationship mitigates the negative effects } \\
\text { of persuasion knowledge on purchase and eWOM intentions. }\end{array}$ \\
\hline
\end{tabular}


Table 2: Measures table

\begin{tabular}{|c|c|c|}
\hline Constructs & Study 1 & Study 2 \\
\hline \multicolumn{3}{|l|}{$\begin{array}{l}\text { Manipulative intent } \\
\text { Study 1: } \alpha=.86, \mathrm{CR}=.92, \mathrm{AVE}=.70 ; \text { Study } 2: \alpha=.85, \mathrm{CR}=.89, \mathrm{AVE}=.59 \\
\text { Source: } \text { Campbell }(1995)\end{array}$} \\
\hline $\begin{array}{l}\text { The way [brand name] tried to influence customers seems acceptable to me. } \\
\text { [reverse coded] }\end{array}$ & .894 & .855 \\
\hline [Brand name] tried to manipulate customers in ways that I don't like. & .783 & .701 \\
\hline $\begin{array}{l}\text { I would be annoyed by [brand name] because they tried to control the } \\
\text { customers inappropriately. }\end{array}$ & .691 & .677 \\
\hline $\begin{array}{l}\text { [Brand name] tried to influence customer without being excessively } \\
\text { manipulative. [reverse coded] }\end{array}$ & $.469^{\mathrm{a}}$ & $.446^{\mathrm{a}}$ \\
\hline [Brand name] was fair in what they said and showed. [reverse coded] & .887 & .905 \\
\hline I think that [brand name]'s response is fair. [reverse coded] & .868 & .906 \\
\hline \multicolumn{3}{|l|}{$\begin{array}{l}\text { Perceived competence } \\
\text { Study 1: } \alpha=.94, \mathrm{CR}=.95, \mathrm{AVE}=.80 ; \text { Study } 2: \alpha=.93, \mathrm{CR}=.95, \mathrm{AVE}=.79 \\
\text { Source: } \text { Xie and Peng (2009) }\end{array}$} \\
\hline I feel that the company is very capable of meeting customer needs. & .884 & .899 \\
\hline I feel confident about the [brand name]'s skill in solving such problems. & .924 & .921 \\
\hline I see no reason to doubt [brand name]'s competence. & .915 & .918 \\
\hline I can rely on [brand name] to meet my expectations. & .932 & .941 \\
\hline I believe [brand name] is able to avoid repetition of such problems. & .821 & .747 \\
\hline \multicolumn{3}{|l|}{$\begin{array}{l}\text { Perceived Honesty } \\
\text { Study 1: } \alpha=.96, \mathrm{CR}=.97, \mathrm{AVE}=.89 ; \text { Study } 2: \alpha=., \mathrm{CR}=., \mathrm{AVE}=. \\
\text { Source: } \text { Xie and Peng (2009) }\end{array}$} \\
\hline [Brand name] is honest. & .924 & .954 \\
\hline [Brand name] has a great deal of integrity. & .952 & .970 \\
\hline [Brand name] has sound principles to guide the company's behaviors. & .956 & .962 \\
\hline [Brand name] has a good value system. & .944 & .964 \\
\hline \multicolumn{3}{|l|}{$\begin{array}{l}\text { Perceived Benevolence } \\
\text { Study 1: } \alpha=.96, \mathrm{CR}=.97, \mathrm{AVE}=.87 ; \text { Study } 2: \alpha=.96, \mathrm{CR}=.97, \mathrm{AVE}=.87 \\
\text { Source: } \text { Xie and Peng (2009) }\end{array}$} \\
\hline [Brand name] has a great deal of consideration for customers. & .936 & .940 \\
\hline [Brand name] favors customers' best interests. & .931 & .946 \\
\hline $\begin{array}{l}\text { [Brand name] treats customers with respect in responding to scandals and } \\
\text { negative publicity. }\end{array}$ & .927 & .928 \\
\hline [Brand name] is concerned about customers. & .936 & .925 \\
\hline $\begin{array}{l}\text { [Brand name] responds constructively and with care when customers have } \\
\text { problems. }\end{array}$ & .943 & .923 \\
\hline \multicolumn{3}{|l|}{$\begin{array}{l}\text { Corporate reputation } \\
\text { Study 1: } \alpha=.75, \mathrm{CR}=.86, \mathrm{AVE}=.68 ; \text { Study } 2: \alpha=.79, \mathrm{CR}=.88, \mathrm{AVE}=.71 \\
\text { Source: Doney and Cannon (1997) }\end{array}$} \\
\hline [Brand name] has a reputation for being honest. & .935 & .940 \\
\hline [Brand name] is known to be concerned about customers & .937 & .931 \\
\hline [Brand name] has a bad reputation in the market. [reverse coded] & $.530^{\mathrm{a}}$ & $.613^{\mathrm{a}}$ \\
\hline \multicolumn{3}{|l|}{$\begin{array}{l}\text { Values-driven motives } \\
\text { Study 2: } \alpha=.91, \mathrm{CR}=.94, \mathrm{AVE}=.84 \\
\text { Source: } \text { Vlacos } \text { et al. }(2009)\end{array}$} \\
\hline [Brand name and SMI] have a long-term interest in customers & -- & .920 \\
\hline $\begin{array}{l}\text { [Brand name and SMI] are trying to support their customers by using these } \\
\text { crisis communications }\end{array}$ & -- & .946 \\
\hline$[$ Brand name and SMI] are trying to reassure custom & -- & .888 \\
\hline
\end{tabular}

Note: ${ }^{\text {a }}$ indicates items with low loadings $(<.6)$ which were removed from the analysis 
Table 3: Serial mediation results (Study 1)

\begin{tabular}{|l|l|c|c|}
\hline \multicolumn{2}{|l|}{ Hypothesized indirect effect } & $\begin{array}{c}\text { Path } \\
\text { coefficient }\end{array}$ & $95 \%$ CI \\
\hline \multirow{4}{*}{$\begin{array}{l}\text { SMI } \\
\text { absent }\end{array}$} & Crisis response $\rightarrow$ Manipulative intent $\rightarrow$ Corporate reputation & .10 & -.09 to .37 \\
\cline { 2 - 4 } & Crisis response $\rightarrow$ Competence $\rightarrow$ Corporate reputation & .06 & -.06 to .26 \\
\cline { 2 - 4 } & Crisis response $\rightarrow$ Honesty $\rightarrow$ Corporate reputation & .13 & -.00 to .37 \\
\cline { 2 - 4 } & Crisis response $\rightarrow$ Benevolence $\rightarrow$ Corporate reputation & .16 & .00 to .37 \\
\cline { 2 - 4 } & $\begin{array}{l}\text { Crisis response } \rightarrow \text { Manipulative intent } \rightarrow \text { Competence } \rightarrow \\
\text { Honesty } \rightarrow \text { Benevolence } \rightarrow \text { Corporate reputation }\end{array}$ & $\mathbf{. 0 5}$ & $\mathbf{. 0 0}$ to. $\mathbf{1 4}$ \\
\hline \multirow{4}{*}{$\begin{array}{l}\text { SMI } \\
\text { present }\end{array}$} & Crisis response $\rightarrow$ Manipulative intent $\rightarrow$ Corporate reputation & .07 & -.05 to .23 \\
\cline { 2 - 4 } & Crisis response $\rightarrow$ Competence $\rightarrow$ Corporate reputation & -.09 & -.23 to .00 \\
\cline { 2 - 4 } & Crisis response $\rightarrow$ Honesty $\rightarrow$ Corporate reputation & -.01 & -.13 to .08 \\
\cline { 2 - 4 } & Crisis response $\rightarrow$ Benevolence $\rightarrow$ Corporate reputation & .10 & .00 to .25 \\
\cline { 2 - 4 } & $\begin{array}{l}\text { Crisis response } \rightarrow \text { Manipulative intent } \rightarrow \text { Competence } \rightarrow \\
\text { Honesty } \rightarrow \text { Benevolence } \rightarrow \text { Corporate reputation }\end{array}$ & $\mathbf{. 0 5}$ & $\mathbf{- . 0 0}$ to .16 \\
\hline
\end{tabular}

Note: Crisis response indicates the comparison between Ingratiation condition (coded as ' 1 ') and No Response condition (coded ' 0 ').

Table 4: Indirect effects (Study 2)

\begin{tabular}{|c|c|c|}
\hline Hypothesized indirect effect & $\begin{array}{c}\text { Path } \\
\text { coefficient }\end{array}$ & $95 \% \mathrm{CI}$ \\
\hline $\begin{array}{l}\text { Crisis response } \rightarrow \text { Manipulative intent } \rightarrow \text { Competence } \\
\text { High values-driven motives: } \\
\text { Crisis response } \rightarrow \text { Manipulative intentions } \rightarrow \text { Competence } \\
\text { Average values-driven motives: } \\
\text { Crisis response } \rightarrow \text { Manipulative intentions } \rightarrow \text { Competence } \\
\text { Low values-driven motives: } \\
\text { Crisis response } \rightarrow \text { Manipulative intentions } \rightarrow \text { Competence }\end{array}$ & $\begin{array}{r}.45 \\
-.02 \\
-.49 \\
\end{array}$ & $\begin{array}{c}.15 \text { to } .78 \\
-.26 \text { to } .21 \\
-.88 \text { to }-.16 \\
\end{array}$ \\
\hline $\begin{array}{l}\text { Crisis response } \rightarrow \text { Manipulative intent } \rightarrow \text { Honesty } \\
\text { High values-driven motives: } \\
\text { Crisis response } \rightarrow \text { Manipulative intentions } \rightarrow \text { Honesty } \\
\text { Average values-driven motives: } \\
\text { Crisis response } \rightarrow \text { Manipulative intentions } \rightarrow \text { Honesty } \\
\text { Low values-driven motives: } \\
\text { Crisis response } \rightarrow \text { Manipulative intentions } \rightarrow \text { Honesty }\end{array}$ & $\begin{array}{r}.53 \\
-.03 \\
-.58 \\
\end{array}$ & $\begin{array}{c}\mathbf{. 1 8} \text { to } . \mathbf{8 8} \\
-.32 \text { to } .24 \\
\mathbf{- 1 . 0 2} \text { to }-.19 \\
\end{array}$ \\
\hline $\begin{array}{l}\text { Crisis response } \rightarrow \text { Manipulative intent } \rightarrow \text { Benevolence } \\
\text { High values-driven motives: } \\
\text { Crisis response } \rightarrow \text { Manipulative intentions } \rightarrow \text { Benevolence } \\
\text { Average values-driven motives: } \\
\text { Crisis response } \rightarrow \text { Manipulative intentions } \rightarrow \text { Benevolence } \\
\text { Low values-driven motives: } \\
\text { Crisis response } \rightarrow \text { Manipulative intentions } \rightarrow \text { Benevolence }\end{array}$ & $\begin{array}{l}.54 \\
-.03 \\
-.59\end{array}$ & $\begin{array}{c}.19 \text { to } .92 \\
-.32 \text { to } .26 \\
-\mathbf{- 1 . 0 4} \text { to }-.20\end{array}$ \\
\hline
\end{tabular}

Note: Crisis response indicates the comparison between Ingratiation response condition and No Response condition. Statistically significant effects are highlighted in bold. 
Appendix A: Study 1's crisis scenario and response

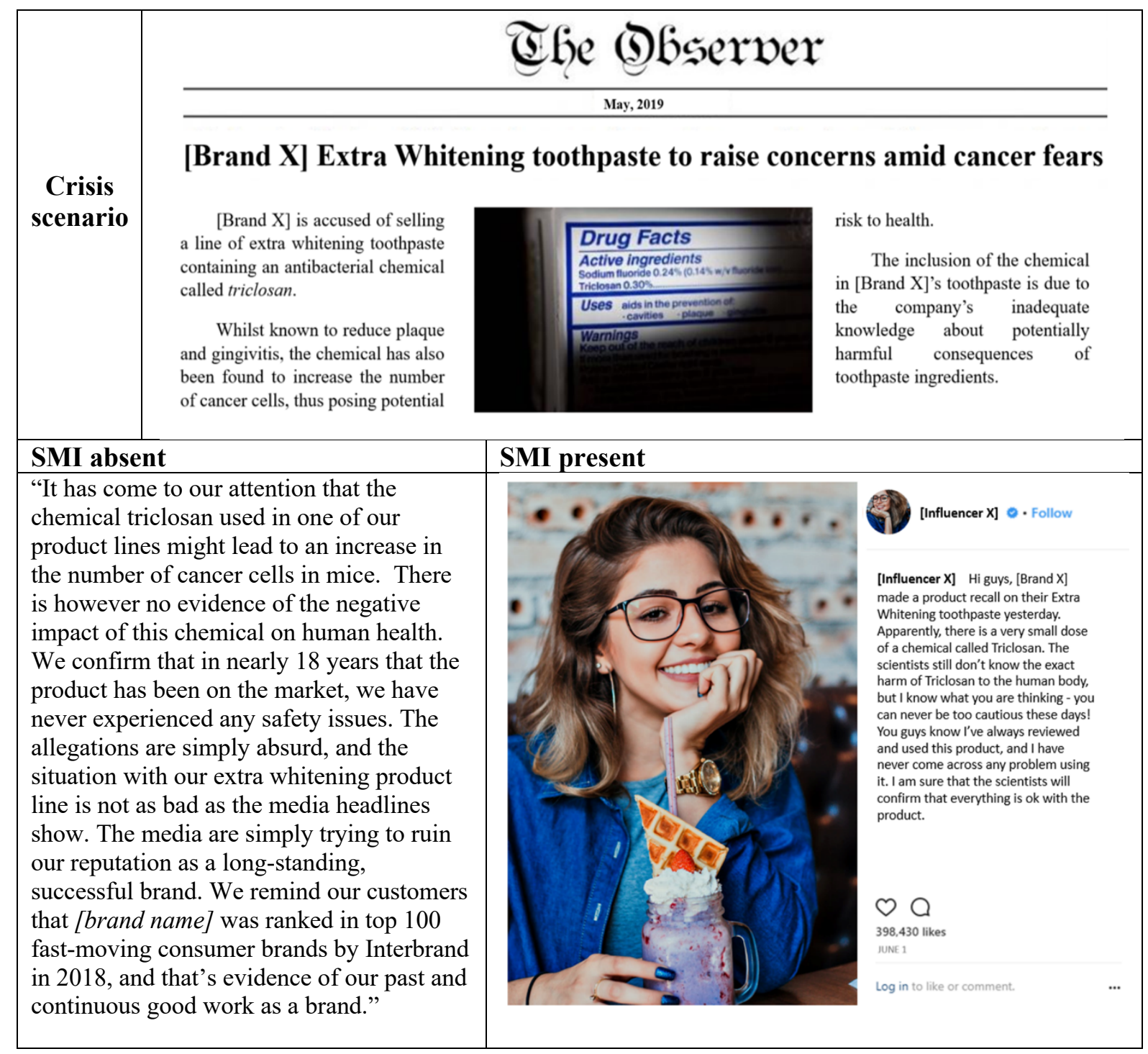


Appendix B: Study 2's crisis scenario and response

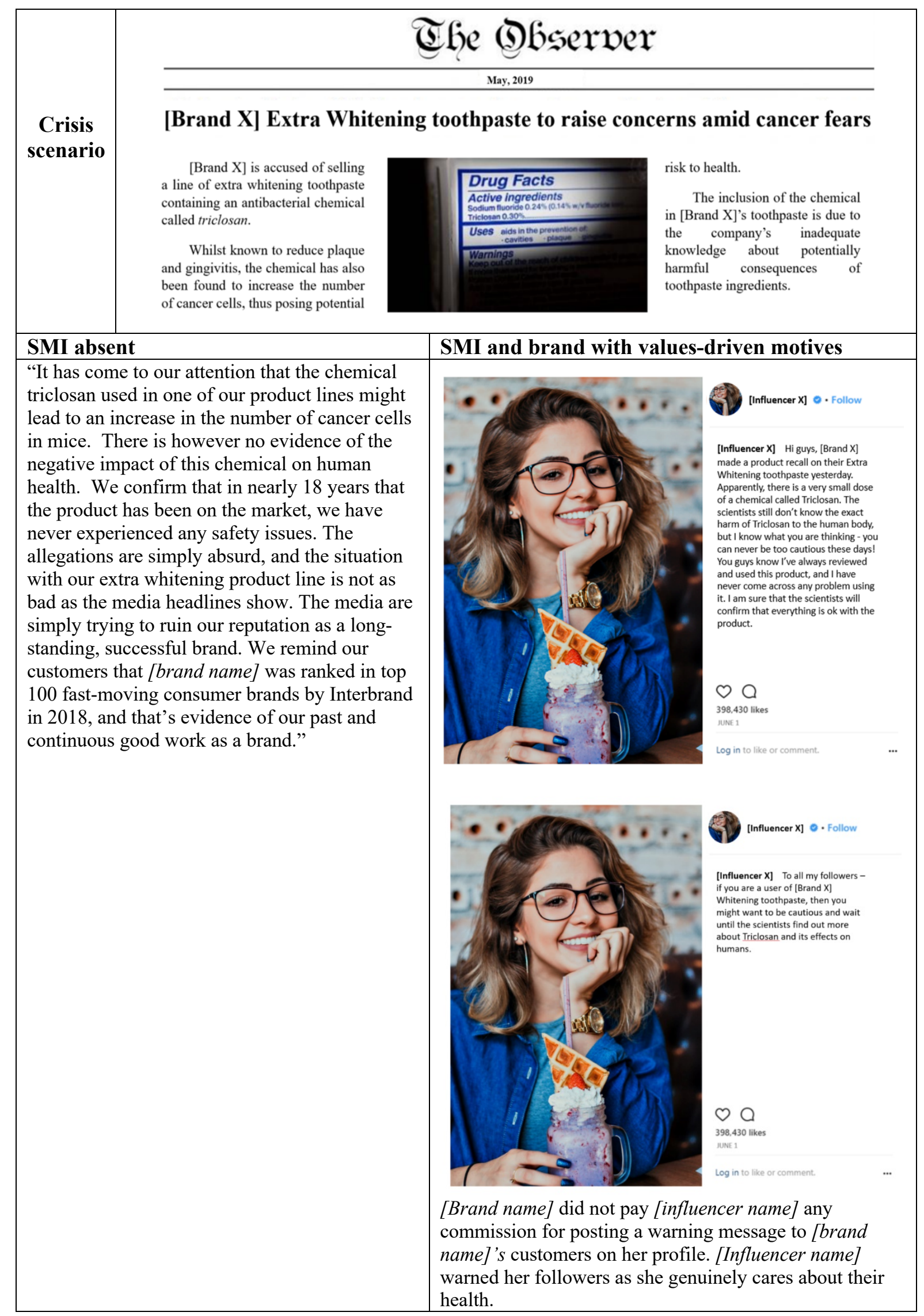


Appendix C: Discriminant validity results (Study 1 and 2)

\begin{tabular}{|l|c|c|c|c|c|c|}
\hline & Competence & Honesty & Benevolence & $\begin{array}{c}\text { Corporate } \\
\text { reputation }\end{array}$ & $\begin{array}{c}\text { Manipulative } \\
\text { intent }\end{array}$ & $\begin{array}{c}\text { Values-driven } \\
\text { motives }\end{array}$ \\
\hline Competence & $\mathbf{. 8 9 6 / . 8 8 8}$ & & & & & \\
\hline Honesty & $.777 / .790$ & $\mathbf{. 9 4 4 / . 9 6 2}$ & & & & \\
\hline Benevolence & $.755 / .775$ & $.910 / .916$ & $\mathbf{. 9 3 5 / . 9 3 3}$ & & & \\
\hline Corporate reputation & $.715 / .759$ & $.781 / .833$ & $.807 / .835$ & $\mathbf{. 9 5 2 / . 8 4 2}$ & & \\
\hline Manipulative intent & $-.694 /-.619$ & $-.775 /-.780$ & $.790 /-.792$ & $-.727 /-.742$ & $\mathbf{- . 8 3 7 / . 7 6 6}$ & \\
\hline $\begin{array}{l}\text { Values-driven } \\
\text { motives }\end{array}$ & $--/ .719$ & $--/ .808$ & $--/ .862$ & $--/ .788$ & $--/-.742$ & $--/ .918$ \\
\hline
\end{tabular}

Note: The values in italics relate to Study 2. All other values relate to Study 1.

The sign -- indicates that this value is not computed in Study 1, but Study 2 only.

Appendix D: Correlations table (Study 1 and 2)

\begin{tabular}{|l|c|c|c|c|c|c|}
\hline & Competence & Honesty & Benevolence & $\begin{array}{c}\text { Corporate } \\
\text { reputation }\end{array}$ & $\begin{array}{c}\text { Manipulative } \\
\text { intent }\end{array}$ & $\begin{array}{c}\text { Values-driven } \\
\text { motives }\end{array}$ \\
\hline Competence & - & $.748^{*}$ & $.722^{*}$ & $.711^{*}$ & $-.553^{*}$ & $.672^{*}$ \\
\hline Honesty & $.775^{*}$ & - & $.916^{*}$ & $.845^{*}$ & $-.744^{*}$ & $.795^{*}$ \\
\hline Benevolence & $.753^{*}$ & $.910^{*}$ & - & $.849^{*}$ & $-.750^{*}$ & $.855^{*}$ \\
\hline $\begin{array}{l}\text { Corporate } \\
\text { reputation }\end{array}$ & $.710^{*}$ & $.780^{*}$ & $.808^{*}$ & - & $-.725^{*}$ & $.787^{*}$ \\
\hline Manipulative intent & $-.667^{*}$ & $-.752^{*}$ & $-.765^{*}$ & $-.700^{*}$ & - & $-.670^{*}$ \\
\hline $\begin{array}{l}\text { Values-driven } \\
\text { motives }\end{array}$ & -- & -- & -- & -- & -- & - \\
\hline
\end{tabular}

Note: The coefficient below/above the diagonal line relate to Study 1/Study 2.

* indicates that the coefficient is significant at $p<.01$.

Appendix E: Consumer reactions to different crisis response and response sources (Study 1)
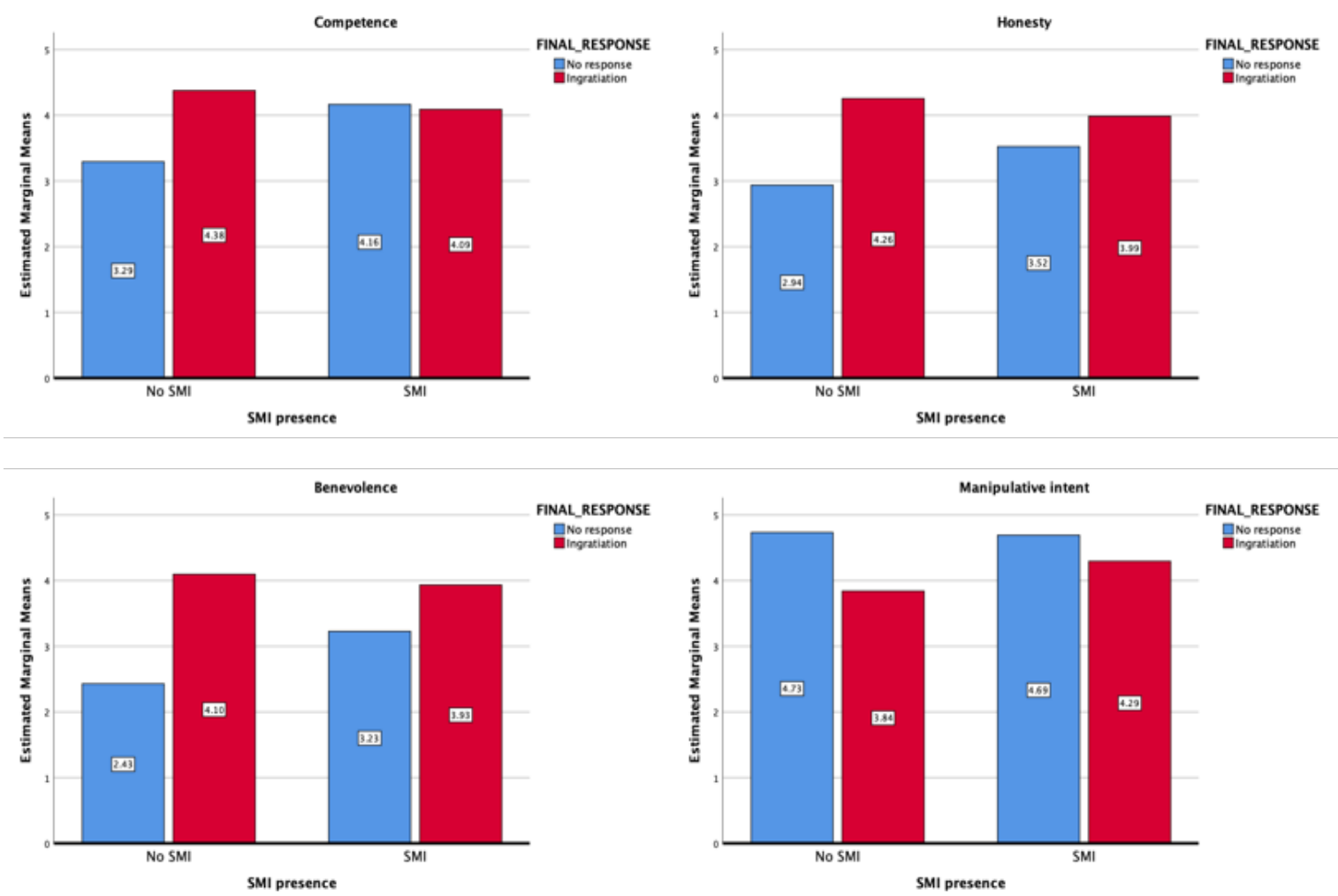
Appendix F: Consumer reactions to different crisis response and response sources (Study 2)
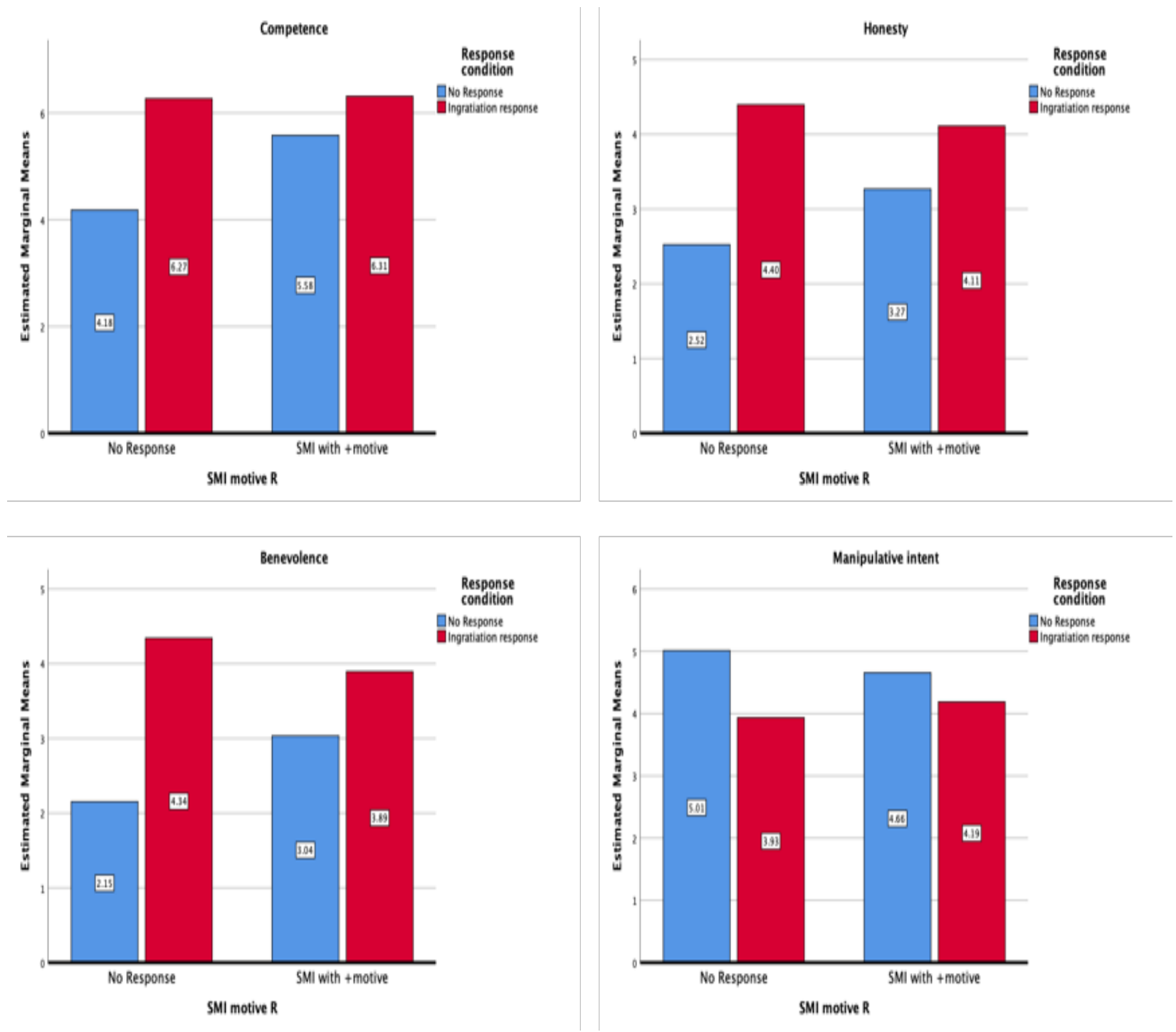